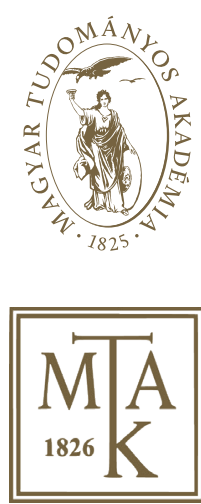

SZÉKFOGLALÓ ELŐADÁSOK A MAGYAR TUDOMÁNYOS AKADÉMIÁN

\title{
SOLYMOSI LÁSZLÓ
}

\section{SZENT LÁSZLÓ KIRÁLY SÍRJA, KULTUSZA ÉS SZENTTÉ AVATÁSA}


- 
Solymosi László

\author{
SZENT LÁSZLÓ KIRÁLY SÍRJA, \\ KULTUSZA ÉS SZENTTÉ AVATÁSA
}


Székfoglaló előadások a Magyar Tudományos Akadémián 
Solymosi László

\section{SZENT LÁSZLÓ KIRÁLY SÍRJA, KULTUSZA ÉS SZENTTÉ AVATÁSA}

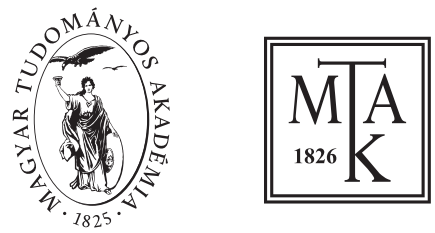

Magyar Tudományos Akadémia, 202I 
A rendes tagsági akadémiai székfoglaló előadás elhangzott 20I6. október I3-án. A szöveg az elhangzott előadás szerkesztett változata.

(C) Solymosi László, 202I

(c) Magyar Tudományos Akadémia, 202I

Magyar Tudományos Akadémia

I05I Budapest, Széchenyi István tér 9.

mta.hu

A Magyar Tudományos Akadémia megbízásából kiadja az MTA Könyvtár és Információs Központ.

A kiadásért felel: Freund Tamás, az MTA elnöke

Nyelvi lektor: Földes Zsuzsanna

Borítóterv és tördelés: Szabó Éva | avesophia.hu

Borítókép: MTA Székház, Díszterem (Mudra László fotója)

Nyomdai munkálatok: Prime Rate Kft.

ISSN I419-8959

ISBN 978-963-508-982-6

DOI I0.36820/szekfoglalo.202I.solymosi

Minden jog fenntartva! 


$$
\begin{aligned}
& \text { „...bünös vagyok, mert } \\
& \text { a földi hatalmat a leg- } \\
& \text { súlyosabb vétkek nélkül } \\
& \text { nem lehet gyakorolni...” }
\end{aligned}
$$

A mottó Szent László király (I077-I095) leveléből való. ${ }^{\mathrm{A}} \mathrm{Az}$ idézett részlet ${ }^{2}$ a kor felfogásával összhangban fogalmazta meg a halandó ember, a bűn és a hatalom kapcsolatát. Itt azonban ennél többről van szó: egy keresztény uralkodó önkritikus vallomásáról. László bűnösnek érezte magát, de kortársai becsülték, a legnagyobbak közé számították, és hamarosan kialakult tisztelete szentté avatásához vezetett.

Ez a tanulmány három kérdésre kíván választ adni: Hová temették László királyt? Hogyan bontakozott ki a kultusza? Miként avatták szentté?

Bár az első kérdésre adott válaszom néhány éve ismert, szükséges, hogy röviden itt is foglalkozzam vele, mivel meghatározón összefügg a másik két kérdéssel. ${ }^{3}$

\footnotetext{
I A székfoglaló előadás szerkesztett formában ugyanezen címmel megjelent a következő tanulmánykötetben: Szent király, lovagkirály. A Szent László-herma és koponyaereklye vizsgálatai. Szerk. Kristóf Lilla Alida - LUKÁcsı Zoltán - Patonay Lajos. Győr, 20I7, i6-39. A jelen közlés ezen alapul, de figyelembe veszi a szentté avatásról szóló rész némileg bővített változatait is: László király szentté avatása a I2. század végén. In: „Mesternek gyengyének”. Ünnepi kötet Madas Edit hetvenedik születésnapja tiszteletére. Szerk. Hende Fanni - KISDI Klára - KorOndi Ágnes. Budapest, 2020, 533-546; Heiligsprechung des ungarischen Königs Ladislaus im ausgehenden I2. Jahrhundert. Mitteilungen des Instituts für Österreichische Geschichtsforschung (= MIÖG) I28 (2020), I35-I46.

${ }^{2}$ A Monte Cassino apátjához I09I-ben írt levélben a következő részlet olvasható: Quamvis peccator existam, quoniam cura terrene dignitatis absque gravissimis non potest premoveri criminibus, tamen tue sanctitatis culmen non ignoravi. In: Diplomata Hungariae antiquissima. Accedunt epistolae et acta ad historiam Hungariae pertinentia. I. Ab anno Iooo usque ad annum II3I. Edendo operi praefuit Georgius Györffy. Adiuverunt Johannes Bapt. Borsa, Franciscus L. Hervay, Bernardus L. Kumorovitz et Julius MoravcsiK. Budapestini I992 (= DHA), 272 (9I. szám).

${ }^{3}$ A jelen írásnak a temetkező helyre vonatkozó részét bővebb változatban lásd Solymosı László: Egy tévedés nyomában. Szent László király somogyvári temetésének legendája. In: Örökség és küldetés. Bencések Magyarországon. Szerk. Illés Pál Attila - JuHÁsz-LACzıк Albin. Budapest, 20I2, I. I5I-I7I. Vö. Solymosı László: Szent László király somogyvári sírjának legendája. In: Magyar történettudomány az ezredfordulón. Glatz Ferenc 7o. születésnapjára. Szerk. GecsÉNYı Lajos - IzsÁK Lajos. Budapest, 20II, I25-I42.
} 


\section{A KIRÁLY SíRJA}

Szent László király I095-ben távozott az élők sorából. Sírhelyét a források egyértelműen meghatározták: az uralkodót az általa alapított váradi székesegyházban temették el. Mátyás Flórián történész (I8I8-I904) I900. június II-én a Magyar Tudományos Akadémia Il. Osztályának felolvasóülésén ismertette új elképzelését. ${ }^{4}$ Eszerint Szent László királyt először az ugyancsak általa alapított somogyvári bencés apátságban temették el, majd onnan vitték később - valamikor II92 előtt földi maradványait Váradra, és helyezték el a székesegyházban.

Mátyás Flórián véleménye gyorsan elterjedt, és állításának egészen napjainkig csak kevesen mondtak ellent. ${ }^{5}$ A kételkedésben a legmesszebb Tóth Sándor művészettörténész (1940-2007) jutott, amikor 200I-ben leírta, hogy „Tihany és Szekszárd vitathatatlanul királyi temetkezőhelyül szolgált, Somogyvár ilyen szerepe viszont kétségbe vonható".

Mátyás Flórián nézetét megelőzően a történeti feldolgozások és maguk a források is kivétel nélkül váradi temetésről tanúskodnak. A Szent László-legenda (a továbbiakban: Legenda) I20o táján megformált két változata, a I4. századi krónikaszerkesztmény Szent László halála után készült része, Kézai Simon I285 táján megfogalmazott gesztája és a Váradi krónika semmit sem tud a somogyvári temetésről.7 A Legenda két változata azonban többletet ad az előbbi forrásokhoz képest. A váradi temetést csodás esemény leírásával, az ún. „kocsi-csodával”

\footnotetext{
${ }^{4}$ Mátyás Flórián: Szent László és Imre királyok végnapjai és II. Endre életévei, fogsága és temetése. (Akadémiai értekezések. II. Oszt., XIX/I.) Budapest, I900, I3-I6.

${ }^{5}$ BALOGH Jolán: Varadinum. Várad vára. I-Il. (Művészettörténeti Füzetek, 13/I-2.) Budapest, I982, I. I3, p., II. 24; Klaniczay Gábor: Az uralkodók szentsége a középkorban. Budapest, 2000, I55-I56; Uő: Holy Rulers and Blessed Princesses. Dinastic Cults in Medieval Central Europe. Cambridge, 200I, I75.

${ }^{6}$ Tо́тн Sándor: A II-I2. századi Magyarország Benedek-rendi templomainak maradványai. In: Paradisum plantavit. Bencés monostorok a középkori Magyarországon / Benedictine Monasteries in Medieval Hungary. Szerk. TAKÁcs Imre. Pannonhalma, 200I, 239, 262 (6I. jegyzet). A kötet a kérdésben nem egységes. Az egyik tanulmány szerzője lehetségesnek tartja a feltárt objektum kapcsolatát Szent Lászlóval, míg a másiké nem vesz tudomást a somogyvári királysírról. PAPP Szilárd: Somogyvár. Uo. 352; HervaY L. Ferenc: A bencések és apátságaik története a középkori Magyarországon. Történeti katalógus. Uo. 509-5II.

${ }^{7}$ Scriptores rerum Hungaricarum tempore ducum regumque stirpis Arpadianae gestarum. (= SRH) I-II. Edendo operi praefuit Emericus SzentpéTERY. Budapestini I937-I938 (utánnyomás és kiegészítés: Az Utószót és Bibliográfiát összeállította, valamint a Függelékben közölt írásokat az l. kiadás anyagához illesztette és gondozta SzovÁK Kornél és VeszPrÉmy László. Budapest, I999), I. I82, 204, 209, 420 , Il. 522-523.
} 
nyomatékosítja: a kocsi a király holttestével magától elindul Várad felé. ${ }^{8}$ Ezt a jelenetet a I4. században a Képes krónika illuminátora is megörökítette $\left(5 \mathrm{I}^{\mathrm{r}}\right)$, noha maga a szöveg nem szólt róla (I. kép). ${ }^{9}$ Ugyanakkor a Magyar Anjou legendárium miniátora is megfestette a történetet, s ábrázolását a kép alá írt szöveg (quomodo currus ibat cum corpore Waradinum) tette egyértelművé (2. kép). ${ }^{\text {Io }} \mathrm{A}$ kocsi-csoda népszerűségét mutatja, hogy a középkori Szent László-beszédek közel felében olvasható ez a jelenet."

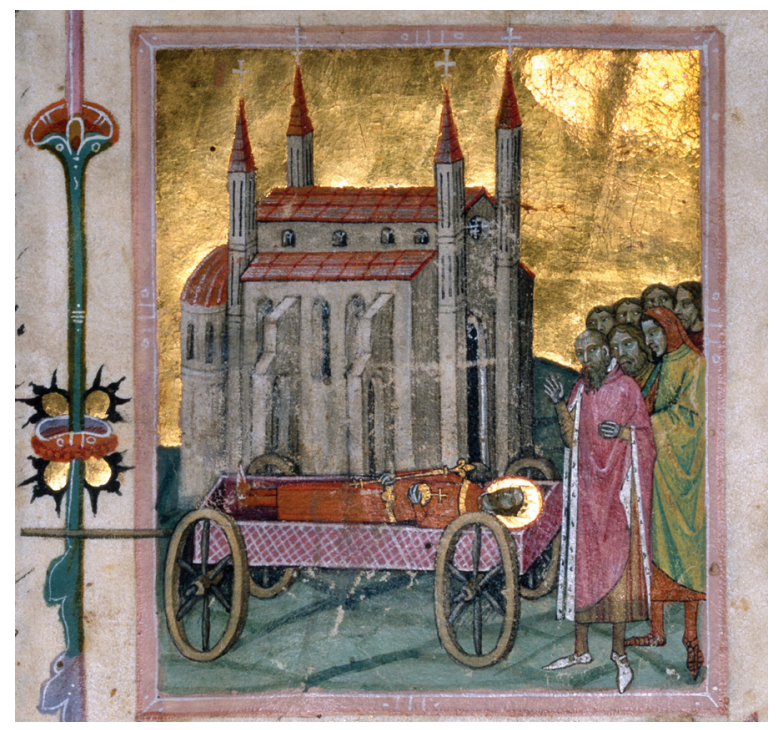

I. kép: Kocsi-csoda: a halottas kocsi magától indul Váradra (Országos Széchényi Könyvtár, Képes krónika $5 \mathrm{I}^{\mathrm{r}}$ )

\footnotetext{
${ }^{8}$ SRH Il. 522-523.

${ }^{9}$ CSAPOdiné GÁRdonyı Klára: A Képes Krónika miniatúrái. In: Képes Krónika. Fordította Bellus Ibolya. A kísérő tanulmányokat DercsénYı Dezső, Kristó Gyula és CsApodiné GárdonYı Klára, a jegyzeteket KRistó Gyula írta. (Pro memoria) Budapest, I986, 547-548.

Io Magyar Anjou legendárium. A bevezető tanulmányt írta, a legendaszövegeket összeállította és a kiadást sajtó alá rendezte LeVÁrdy Ferenc. Budapest, 1973, XLIV/I9. kép. Vö. Kerny Terézia: Szent László halála és temetése a képzőművészetben. In: Bogyay Tamás emlékére. Szerk. BERTÉNYı lván DóKA Klára. (Magyar Egyháztörténeti Évkönyv / Annales historiae ecclesiae Hungaricae, 2.) Budapest, 1996, 75 .

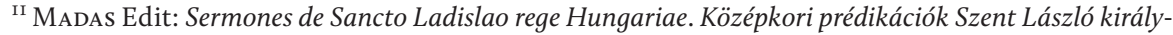
ról. Kétnyelvű kiadás. (АГАӨА, I5) Debrecen, 2004, 7, 44-45, 304-305.
} 


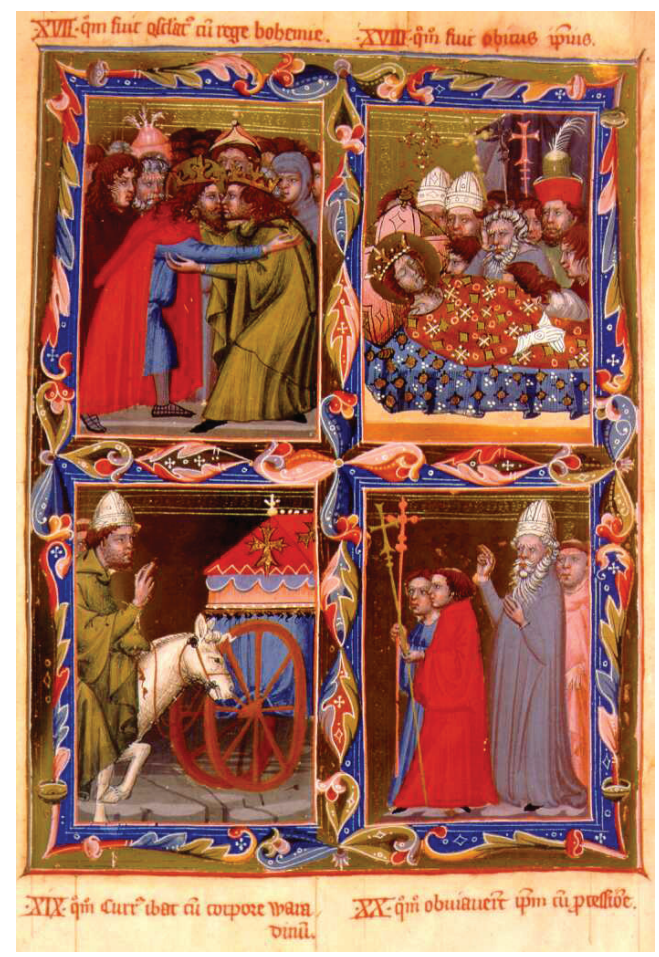

2. kép: Négy jelenet a legendáriumból: László király és a cseh uralkodó békecsókja; a király halála; a király holttestét a kocsi Váradra viszi; körmenettel mennek elébe (Biblioteca Apostolica Vaticana, Vat. Lat. 854I. fol. 84 $4^{\mathrm{r}}=$ Magyar Anjou legendárium, XLIV/I7-20. kép)

Vajon mi késztette akkor Mátyás Flóriánt az addig általánosan uralkodó álláspont felülbírálására? Mátyás egy olyan bullára, pontosabban annak egy kis részletére hivatkozik, amelyet Il. Paszkál pápa állított ki ııo6. november 2-án, a dél-franciaországi (languedoci) saint-gilles-i bencés apátság élén álló Hugó apát számára. ${ }^{22}$ A kapcsolatot az jelenti, hogy Szent László király iogi-ben az innen érkező szerzetesek számára építtette a somogyvári monostort a Szentháromság, Szent Péter és Pál apostolok, valamint Szent Egyed, a híres francia apátság védőszentje tiszteletére. ${ }^{13}$

\footnotetext{
${ }^{2}$ DHA I. 352-353 (I29. szám).

${ }^{13}$ DHA I. 266-268 (88. szám).
} 
Ez az oklevél nem volt ismeretlen a magyar kutatás előtt. Először I774-ben Pray György, ${ }^{14}$ majd mások is közzétették a forrás szövegét, ${ }^{15}$ azonban senki sem következtetett belőle Szent László somogyvári temetésére.

Mátyás Flórián I900-ban közzétett nézetének bírálata még ugyanabban az évben megjelent. Recenziójában Pauler Gyula (I84I-I903) kiemelten foglalkozott a somogyvári temetés kérdésével. ${ }^{16}$ Kifogásolta, hogy Mátyás Flórián kihagyásokkal idézte a bulla vonatkozó részét. Arra a (téves) következtetésre jutott, hogy nem a magyar király, hanem Odiló saint-gilles-i apát teste nyugodott Somogyvárott. Úgy vélte, számos hiteles adat tanúskodik arról, hogy László király testét mindjárt Váradon temették el; azt pedig, hogy ideiglenesen Somogyvárott lett volna eltemetve, a másképp is magyarázható bullán kívül semmi sem bizonyítja.

Mátyás Flórián nem válaszolt ezekre az ellenvetésekre. Nem sokkal később mindketten távoztak az élők sorából. Haláluk után a kérdéssel a középkorkutató történésznek készülő fiatal Baumgarten Ferenc Ferdinánd (I880-1927) foglalkozott. Baumgarten a pesti egyetemen doktorált 1903-ban, majd a strassburgi egyetemen folytatta tanulmányait. ${ }^{17} \mathrm{~A}$ két bencés apátság, Somogyvár és Saint-Gilles közös múltjának feltárására vállalkozott. Baumgarten Mátyás Flórián nézete mellett érvelt, és azt állította, hogy a bulla vonatkozó passzusa csak egyféleképpen értelmezhető: igenis Szent Lászlót temették el Somogyvárott. ${ }^{18}$ Új elemként hozta fel, hogy a saint-gilles-i anyaapátságban a I2. század elején készült halottaskönyv feljegyezte Szent László temetése napját. ${ }^{19}$

Ez a feljegyzés azonban azzal függött össze, hogy az egyházalapítás, az egyháznak tett adomány lélekváltság-adomány volt. A temetés évfordulóin a meg-

\footnotetext{
${ }^{\mathrm{I} 4}$ Georgius PraY: Dissertatio historico-critica de Sancto Ladislao Hungariae rege. Posonii I774, 47-50.

${ }^{15}$ A kiadások felsorolását lásd DHA I. 352.

${ }^{16}$ PAuler Gyula bírálatát Mátyás Flórián értekezéséről lásd Századok 34 (I900), 738-740. A temetésről a 739. lapon írt.

${ }^{17}$ TÉGLÁs János: „a nagyvilág fáradt zarándoka”. Baumgarten Ferenc élete. In: A Baumgarten Alapítvány. Dokumentumok I94I-I95I. V. Szerkesztette, a szöveget gondozta, a jegyzeteket, valamint a függeléket írta és összeállította TÉGLÁs János. Budapest, 2007, 30I-3II, különösen 303.

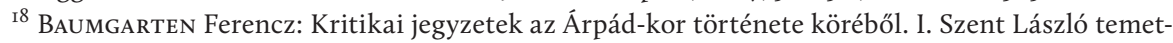
kező helye. Századok 38 (1904), 868-871; Uő: Levél a szerkesztőhöz. Uo. 994-996.

${ }^{19}$ A forrásadat azóta kiadásban is elérhető: Ulrich Winzer: S. Gilles: Studien zum Rechtsstatus und Beziehungsnetz einer Abtei im Spiegel ihrer Memorialüberlieferung. Bestandteil des Quellenwerkes Societas et Fraternitas. (Münstersche Mittelalter-Schriften, 59.) München, I988, 376.
} 
adományozott intézmény papsága imádkozott jótevője túlvilági boldogulásáért, függetlenül attól, hová temették. ${ }^{20}$ Így természetes volt, hogy mind a somogyvári, mind a közvetve érintett francia apátságban nyilvántartották László temetése napját, és imádkoztak érte.

Baumgarten meghívott vendégként 1905. november I3-án előadást tartott a Magyar Tudományos Akadémia Il. Osztályának ülésén, ahol felolvasta tanulmányát a somogyvári és a saint-gilles-i apátságok kapcsolatáról. Fejérpataky László (I857-I923) úgy mutatta be az ifjú szerzőt, mint aki korábbi munkájában „Szent László temetése helyének kérdését is jóformán eldöntötte”. ${ }^{21}$

Baumgarten nem sokkal ezután ${ }^{22}$ felhagyott a középkorkutatással, esztétikai és színháztudományi műveket alkotott. Nevét szélesebb körben a magyar írók támogatására tett nagyvonalú alapítványa, a Baumgarten-díj őrizte meg, amelyet I949-ben osztottak ki utoljára.

Mátyás Flórián és Baumgarten nézete szinte mindenkit meghódított. Békefi Remig (I858-I924), Sörös Pongrác (I873-I9I9), majd Karácsonyi János (I858-I929) is azt vallotta, hogy Szent Lászlót először a somogyvári monostorban temették el.23 Dercsényi Dezső (I9IO-I987) művészettörténész a vita ismeretében így írt: „Semmi okunk sincs, hogy László somogyvári eltemetését tényként el ne fogadjuk."24

A téves nézet terjedése I960 után újabb lendületet kapott. Györffy György (19I7-2000) történeti földrajzában még azt írta, hogy I095-ben a váradi székesegyházban temették el az alapító királyt, ${ }^{25}$ de I977-ben már amellett tette le vok-

\footnotetext{
${ }^{20}$ Solymosı László: Hozott-e törvényt Szent István király a torlókról? In: Doctor et apostol. Szent Istvántanulmányok. Szerk. TöRök József. (Studia Theologica Budapestinensia, Io.) Budapest, I994, 229-232.

${ }^{21}$ [TASNÁdi NAGy Gyula:] Vegyes közlések. Századok 39 (1905), 976.

${ }^{22}$ Újabb és egyben utolsó középkori témájú cikkében már nem tért ki a temetés kérdésére. BAUMGARTEN Ferencz: A saint-gillesi apátság összeköttetése Magyarországgal. Diplomatikai tanulmány. Századok 40 (1906), 393-394, 395, 398, 4I0.

${ }^{23}$ BÉKEFI Remig: A Balaton környékének egyházai és várai a középkorban. Budapest, I907 (újranyomás: Budapest, 2009), I93; Sörös Pongrácz: Az elenyészett benczés apátságok története. (A pannonhalmi Szent-Benedek-rend története, XII/B.) Budapest, I9I2, I5I-I52 (5. jegyzet); KARÁcsonYI János: Szent László király élete. Budapest, I926, 94-96.

${ }^{24}$ DercsénYı Dezső: A somogyvári Szent Egyed-apátság maradványai. Doktori értekezés. Budapest, I934, II-I2 (2I. jegyzet), I8.

${ }^{25}$ GyÖRfFy György: Az Árpád-kori Magyarország történeti földrajza / Geographia historica Hungariae tempore stirpis Arpadianae. I. Budapest, I963, ${ }^{2}$ I966, 685. Vö. uo. 682.
} 
sát, hogy Szent Lászlót előbb Somogyvárott, majd Váradon temették el. ${ }^{26}$ Sokan mások is hasonlóan vélekedtek, többek között Csóka J. Lajos (I904-I980) bencés rendtörténész, illetve Bálint Sándor (1904-1980), a szakrális néprajz tudósa. ${ }^{27}$

A téves állítás az I970-es évek végétől a szövegkiadásokban és fordításaikban is megjelent. A kiadók és a fordítók itthon és külföldön lábjegyzetben figyelmeztették az olvasót, hogy először a somogyi monostorban, s nem Váradon volt a temetés. Ez a gyakorlat sokáig nem érvényesült a Legenda (a továbbiakban: Legenda) esetében. De végül az újabb fordítás itt is igazodott hozzá. Úgy jelent meg, hogy emlékeztetett a somogyi temetésre. ${ }^{28}$

Ezen a vélekedésen a somogyvári monostor 1972-ben megkezdett régészeti feltárása sem változtatott. Bakay Kornél, az ásatást vezető régész eleve abból indult ki, hogy a királysírnak meg kell lennie. A szentélytől távol, a főhajóban talált is egy építményt, melyet kriptának minősített. Bakay számos helyen és alkalommal írt a somogyvári királysírról. ${ }^{29}$ Néhány évvel ezelőtt impozáns kiállítású könyvben foglalta össze több évtizedes kutatásainak eredményeit. ${ }^{30}$

I99I nyarán Somogyvárott az apátság alapításának 900 éves évfordulója alkalmából tudományos ülésszakot rendeztek, és ünnepélyesen átadták a helyreállított műemléket (3. kép), megjelölve benne Szent László királynak a sírfelirat

\footnotetext{
${ }^{26}$ GyöRfFy György: A „lovagszent” uralkodása. Történelmi Szemle 20 (I977), 56I, 563. Vö. Uő: A magyar állam megszilárdulása. In: Magyarország története tíz kötetben. 1/I-2. Előzmények és magyar történet I242-ig. Főszerk. SzÉKely György, szerk. BARTHA Antal. Budapest, I984, I/2. 940, I67I. Időrendi áttekintésben: uo. 1517. Lásd még: GYöRFFY György: Szent László. In: László király emlékezete. Szerk. Katona Tamás. (Bibliotheca Hungarica) H. n., I977, 20. Ugyanezt rögzítette szócikkében is: György GYörfFY: Ladislaus I. der Heilige. In: Lexikon des Mittelalters. V. München-Zürich, I99I, Sp. I6IO-I6II. Vö. DHA I. 352 (3. jegyzet).

${ }^{27}$ CsókA J. Lajos: Szent Benedek fiainak világtörténete különös tekintettel Magyarországra. I-Il. [Budapest, 1970], I. 309, 459. Nézetét a mü német változatában is megismétli: Uő: Geschichte des Benediktinischen Mönchtums in Ungarn. (Studia Hungarica, II.) München, I980, 78, 426; BÁLINT Sándor: Ünnepi Kalendárium. A Mária-ünnepek és jelesebb napok hazai és közép-európai hagyományvilágából. l-ll. Budapest, I977, I. 483, 523.

${ }^{28}$ Solymosi: Egy tévedés nyomában (i. m.) I60-I6I.

${ }^{29}$ BAKAY Kornél: Előzetes jelentés a somogyvári bencés apátság 1972-73. évi feltárásáról. (Somogyi Múzeumok Közleményei, I.) Kaposvár, I973, 345; Uő: Második jelentés a somogyvári bencés apátság feltárásáról (1974-75). (Somogyi Múzeumok Közleményei, II.) Kaposvár, I975, 205; Uő: Feltárul a múlt? A múlt jövője. Budapest, 1989, 279-280, 304; Uő: Somogyvári bencés apátság. In: Magyar Katolikus Lexikon. Főszerk. Dıósı István, szerk. VııZıán János. XII. Budapest, 2007, 230.

${ }^{30}$ BAKay Kornél: Somogyvár. Szent Egyed-monostor. A somogyvári bencés apátság és védműveinek régészeti feltárása 1972-2009. Budapest, 20II, 94-95, I59-I6I, I64-I65. I8I-I86, 53I-532, 555, 56I. A szerző itteni megjegyzéseire tett észrevételeimet lásd Solymosı: Egy tévedés nyomában (i. m.) I69-I70.
} 
szerint feltételezett első sírját (sepulcrum opinabile primum regis Sancti Ladislai) (4. kép). A temetkezés kérdésével is foglalkozó előadók kivétel nélkül tényként kezelték, hogy Szent László első nyughelye a somogyvári monostorban volt. ${ }^{3}$

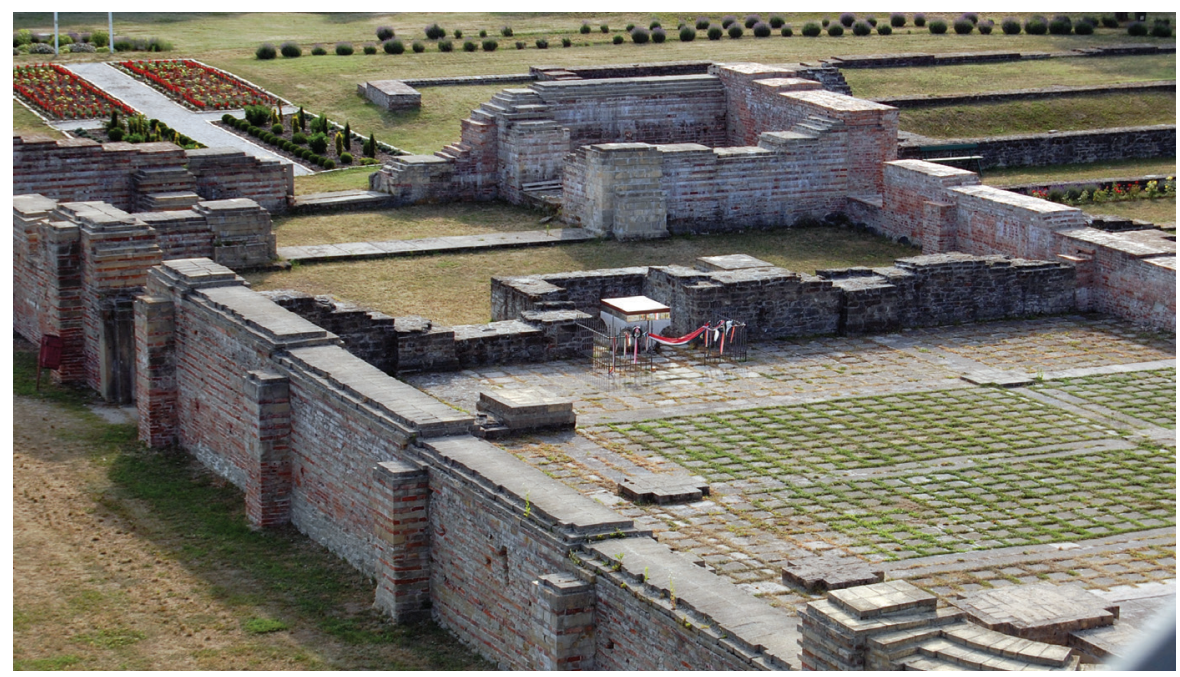

3. kép: A somogyvári apátság a műemléki helyreállítás után a feltételezett sírhellyel (Zágorhidi Czigány Balázs felvétele)

${ }^{3 \mathrm{I}}$ Szent László és Somogyvár. Tanulmányok a 900 éves somogyvári bencés apátság emlékezetére. Szerk. MaGyar Kálmán. Kaposvár, I992, I0, 37, 56-57, I08, I70, 226, 266-267, 289. Györffy György, Magyar Kálmán, Fügedi Erik, Barna Gábor, Tóth Melinda, Levárdy Ferenc, L. Szabó Tünde tanulmányairól van szó. 


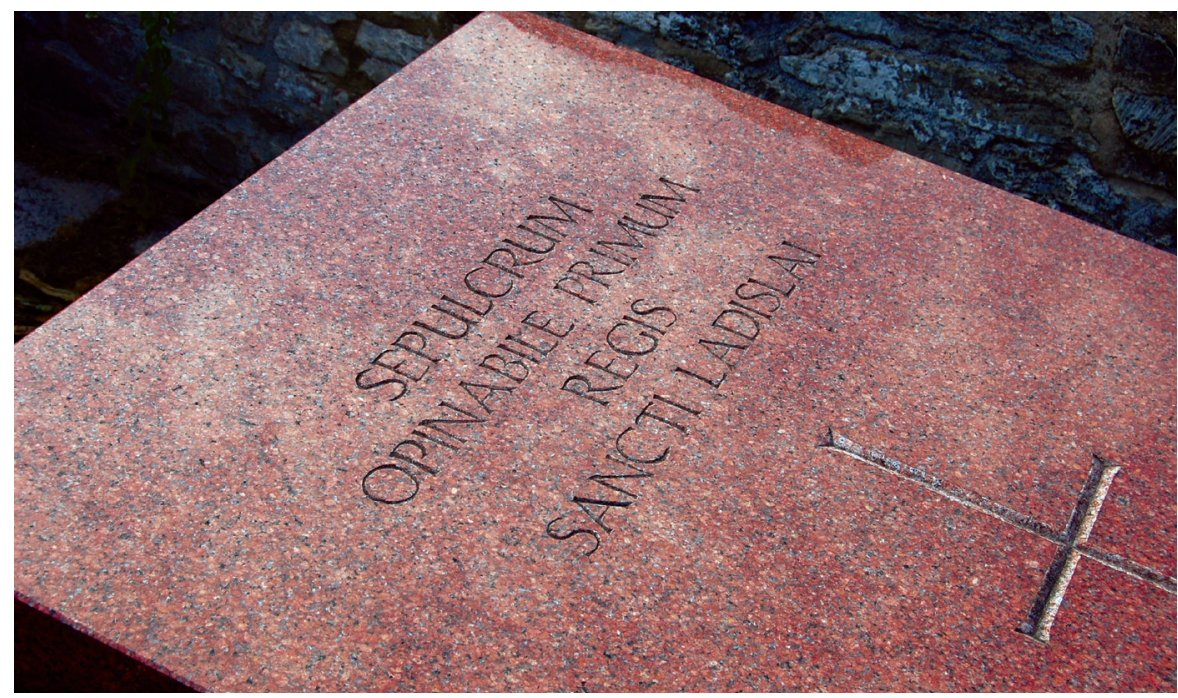

4. kép: A felirat szövege: Sepulcrum opinabile primum regis Sancti Ladislai („Szent László király vélt első sírja”) (Zágorhidi Czigány Balázs felvétele)

Ha a somogyvári monostor valóban királyi temetkezőhely volt, akkor felmerül a kérdés, mikor és hogyan vitték át az I095-ben elhunyt király tetemét a váradi székesegyházba.

A Fügedi Erik (1916-I992) nevéhez köthető datálási kísérlet Gallus Anonymus gesztájára támaszkodik. Ebben szó esik Ill. (Ferdeszájú) Boleszló lengyel fejedelem (IIO2-II38) somogyvári zarándoklatáról. Fügedi feltételezte, hogy a fejedelem Szent László ott levő sírját is felkereste somogyvári tartózkodásakor.32 Ugyanakkor a geszta nem említi a sírt, ami azért is elgondolkoztató, mert más helyütt megemlékezik a magyar uralkodóról.33

\footnotetext{
${ }^{32}$ FüGEDI Erik: Somogyvár francia monostora... In: Szent László és Somogyvár (i. m.) 57. A szerző itt az átvitel időpontját III2-II34 közé teszi. Az utóbbi évszám, az ante quem azonban nyilvánvaló tévedés, mert vélekedésével ellentétben az II34-ben említett váradi oltárról nem mondja az oklevél, hogy kapcsolatban lenne Szent László sírjával. Vö. Chartae antiquissimae Hungariae ab anno IOoI usque ad annum II96. Composuit Georgius GyörfFy. (Monumenta Medii Aevi) Budapest, I994 (= CAH), 46 (I4. szám).

33 BAGı Dániel: Gallus Anonymus és Magyarország. (Irodalomtörténeti füzetek, 157.) Budapest, 2005, I66-I67. Vö. Gesta principum Polonorum. The Deeds of the Princes of the Poles. Translated and annotated by Paul W. Knoll, Frank Schaer. (Central European Medieval Texts, 3.) Budapest - New York, 2003 (utánnyomás: 2007), 96-IOI, I26, 276.
} 
Egy további időpont-meghatározási próbálkozás Valter váradi püspök sajátos istenítéletére épül. ${ }^{34}$ A Legenda szerint Könyves Kálmán király (I095-III6) fia és utóda, azaz Il. István uralkodása (III6-II3I) idején egy ispán lopással vádolt meg egy vitézt, s a király Valter püspököt bízta meg a per befejezésével. A püspök Szent László érdemeiben bízva, annak sírjára helyezte a per tárgyát képező ezüsttálat, hogy Isten döntse el, kit illet meg az ezüstnemű. Amikor az ispán meg akarta ragadni a tálat, félholtan összeesett. ${ }^{35} \mathrm{~A}$ bizonyító eljárás leírását a Legenda két változatban örökítette meg. Az egyik csak az ispán felsüléséről szólt, míg a másik ezt kiegészítette azzal, hogy a vitéz a sírról elveszi a tálat. ${ }^{36} \mathrm{~A}$ bővítés arról árulkodik, hogy szerzője nem lehetett tisztában az istenítéleti eljárással, hiszen az ilyen vitákban csak az egyik felet kötelezték arra, hogy az istenítéleti próbának alávesse magát, s ha ennek során bűnösnek bizonyult, a másik fél magától értetődően megnyerte a pert. A bővebb változat a I4. században a Magyar Anjou legendárium miniátorát is megihlette, és ennek megfelelően két képet készített róla. Az egyiken a földre zuhant ispán, a másikon a vitéz látható, amint a sírról elveszi a tálat (5. kép). ${ }^{37}$

$34 \mathrm{Az}$ esetet istenítéletnek minősítette HoRvÁTH János: Árpád-kori latinnyelvű irodalmunk stílusproblémái. Budapest, I954, I94.

35 SRH II. 524-525.

${ }^{36}$ SRH II. 525 .

${ }^{37}$ Magyar Anjou legendárium (i. m.) XLIV/23-24. kép. 


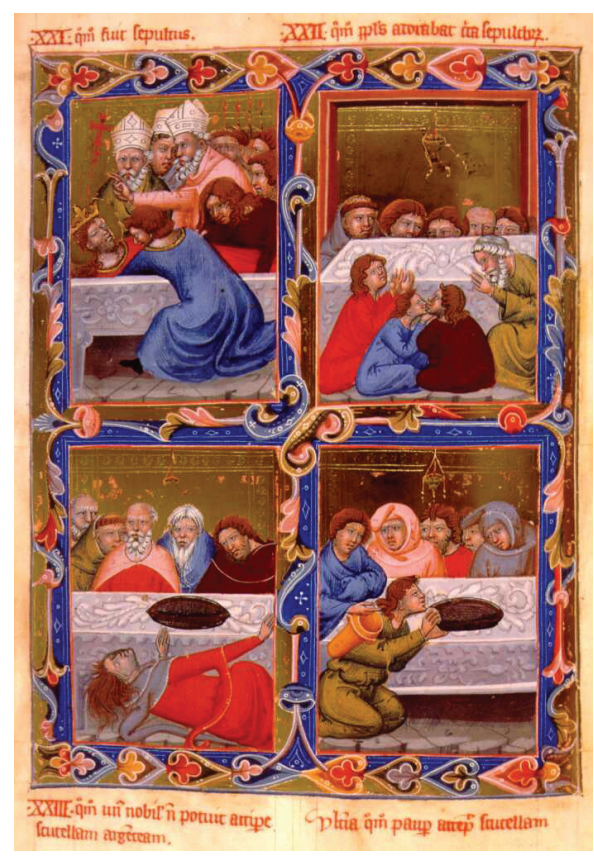

5. kép: Temetés, tisztelet és istenítélet a legendáriumban: László királyt eltemetik; a nép imádkozik a sír körül; a nemes nem tudja felemelni a sírra helyezett ezüsttálat; a szegény ember elveszi az ezüsttálat (Biblioteca Apostolica Vaticana, Vat. Lat. 854I. fol. 85ำ Magyar Anjou legendárium, XLIV/2I-24. kép)

Valter püspök vitathatatlanul történeti személyiség volt. A I4. századi összeállításból ismert váradi püspöklistában ugyan nem szerepel, de oklevelek igazolják létezését. ${ }^{8} \mathrm{Az}$ általa lefolytatott istenítélet időpontját joggal lehet az őt megbízó Il. István király uralkodásának az idejére, vagyis III6 és II3I közé tenni. De ekkorra helyezni az átvitelt Váradra még a somogyvári temetés elfogadása esetén is vitatható. ${ }^{39}$ Felmerül ugyanis a kérdés, miként alakulhatott ki ilyen

\footnotetext{
${ }^{38}$ Zsoldos Attila: Magyarország világi archontológiája I0oo-I30I. (História Könyvtár: Kronológiák, Adattárak, II.) Budapest, 20II, 98. A váradi püspöklista eleje hiányos, az első püspök, azaz Könyves Kálmán után a következő püspök II. Géza korából való. Így Sixtus és utóda, Valter püspök sem szerepel benne. BunYitay Vincze: A váradi káptalan legrégibb statutumai. Nagyvárad, I886, I4; újabb kiadásban: Documenta Romaniae historica. C. Transilvania. XIV (I37I-I375). Ed. Aurel RĂDUŢIU, Viorica Pervain, Susana Andea, Lidia Gross. Bucureşti, 2002 (= Documenta Trans.), 688.

${ }^{99}$ Kerny Terézia: Királyi temetkezések a váradi székesegyházban. In: Váradi kőtöredékek. Szerk. Kenny Terézia. Budapest, I989, I59, I60-I6I (3. jegyzet). Vö. Uő: László király szentté avatása és kultuszának kibontakozása (I095-I30I). In: Ösök, táltosok, szentek. Tanulmányok a honfoglaláskor és Árpád-kor folklórjából. Szerk. Pócs Éva - Volgt Vilmos. Budapest, I996, I76.
} 
rövid idő alatt Szent Lászlónak olyan kultusza Váradon, hogy alig elkészült sírját Valter püspök bevonhatta a sajátos istenítéleti eljárásba.

Az esetleges átvitelt a holttest exhumálásának kellett megelőznie. A kánonjog szerint az egyházi engedéllyel történő kihantolásnak három fő típusa létezett. Ha a temetés után kiderült a halottról, hogy életvitele miatt (például kiközösített volt) nem lett volna szabad megszentelt földbe temetni, akkor kötelezően kihantolták, és a temetőn kívül ásták el a tetemet. A szentté avatást követően is kiemelték (elevatio) addigi sírjából a szent maradványait, hogy végső nyughelyére temessék. Végül az is előfordult, hogy valamilyen egyéb oknál fogva kívánták utóbb máshol elhelyezni az elhunyt földi maradványait. ${ }^{40} \mathrm{~A}$ somogyvári kihantolás ez utóbbi kategóriába tartozott volna, mint IV. Béla király (I235-I270) holttestének sokszor idézett kétszeri exhumálása és háromszori temetése Esztergomban. A királyt i270-ben az esztergomi ferenceseknél temették el, de tetemét az esztergomi érsek kihantoltatta és átvitette a székesegyházba, ahonnan pápai döntés nyomán került vissza eredeti helyére. ${ }^{41} \mathrm{~A}$ részletek nem ismertek. De feltehető, hogy a pápa azért állt a ferencesek mellé, mert a király az ő templomukat választotta temetkezőhelyül, az ott eltemetett kisebbik fia, Béla herceg sírja mellett kívánt nyugodni. ${ }^{42} \mathrm{~A}$ háttérben minden bizonnyal presztízsszempontok és anyagi megfontolások, a királyi temetéssel, az évenként ismétlődő liturgikus cselekménnyel és a sír látogatásával kapcsolatos bevételek álltak.43

Bár a források nem tudnak semmiféle somogyvári exhumálásról, mégis többen megkísérelték összkapcsolni a kettős temetésről szóló elképzelést a Legenda elbeszélésével, a holttest Váradra szállításának csodás történetével. Esze-

\footnotetext{
${ }^{40}$ Szuromi Szabolcs: A temetésre vonatkozó egyházfegyelem a XII-XIII. században. Budapest, 2002, 207-210.

${ }^{4 I}$ SRH I. 469-470. Vö. KaRÁcsONYI János: Szt. Ferencz rendjének története Magyarországon I7II-ig. I. Budapest, I922, I62.

${ }^{42}$ Hasonló vita bontakozott ki II34-ben a magdeburgi székeskáptalan és a helybeli premontrei monostor szerzetesei között arról, hová temessék a premontrei rend alapítóját, Szent Norbertet, aki szerzetes és egyben magdeburgi érsek volt. A vitát Lothar császár döntötte el a szerzetesek javára. Döntésében nyilván része volt annak, hogy Norbert rendtársai között kívánt nyugodni. Szuromi: A temetésre vonatkozó egyházfegyelem... (i. m.) 87-88.

${ }^{43}$ Vö. Solymosı László: Egyházi és világi (földesúri) mortuarium a II-I4. századi Magyarországon. Századok I2I (1987), 557-559; Lőveı Pál: Posuit hoc monumentum pro aeterna memoria. Bevezető fejezetek a középkori Magyarország síremlékeinek katalógusához. Akadémiai doktori értekezés. I. Budapest, 2009, 388-392 („A sír mint egyházi bevételi forrás” című alfejezet).
} 
rint a hívek a nagy nyári meleg és a hosszú út miatt haboztak a holttestet Váradra vinni. Okosabbnak látták a fehérvári egyház mellett dönteni. Egy fogadóhoz érve, a fáradtságtól és a szomorúságtól elcsigázva elaludtak. Miután elnyomta őket az álom, a kocsi, amelyre a testet rakták, mindenféle állati vonóerő nélkül magától megindult Váradra a helyes úton. Ébredés után a hívek mindenfelé keresték, amíg meg nem találták a Várad felé magától futó szekeret. Látván, hogy a király testét isteni erő viszi ama helyre, ahová való temetkezését maga választotta, útjukat habozás nélkül Várad felé vették. ${ }^{44}$

A kocsi-csoda szövegében semmiféle konkrét utalás nincsen a somogyvári temetésre, azaz alkalmatlan arra, hogy valamiképpen az itteni eltemetést bizonyítsa. Ezért több kimódolt magyarázat kísérelte meg összhangba hozni a történetet a somogyvári helyszínnel. Karácsonyi János például a kocsi-csodát istenítéletnek tekintette. Feltevése szerint a váradi püspök kérte meg arra Il. Istvánt, hogy a király végakaratának megfelelően vitesse Váradra Szent László tetemét. Vita kerekedett a somogyiak és a váradi püspök között, és Il. István istenítéletre bízta ennek eldöntését. Kihantoltatta a koporsót, és szekérre rakatta, hogy lássák, merre indul el a kocsi. A szekér Várad felé indult, így az istenítélet nyomán a somogyvári bencések kénytelenek voltak lemondani a királysírról.45

A kocsi-csoda története nem szolgált egyebet, mint annak az egyházjogi követelménynek a tudatosítását, amely szerint bárki végakaratát teljesíteni kell, semmi okkal, még a kánikula miatt sem lehet kitérni előle. ${ }^{46}$

Miután nem találtunk valamire való választ arra, mikor miért és hogyan került volna a holttest Somogyvárról Váradra, vissza kell térnünk a többször említett pápai bullához. A megoldás ebben rejlik.47

\footnotetext{
${ }^{44}$ SRH Il. 522-523. A csoda teljes szövegét Kurcz Ágnes fordításában lásd Árpád-kori legendák és intelmek. A válogatás, a bevezető tanulmány, a jegyzetek és a szöveggondozás ÉRszEGı Géza munkája. Budapest, 1983, 99-100.

${ }^{45}$ KarÁcsonyı: Szent László... (i. m.) 94-96. Vö. SőTÉR István: Francia-magyar művelődési kapcsolatok. Budapest, I94I, 4; Uő: Magyar-francia kapcsolatok. Budapest, I946, I3.

${ }^{46}$ Szuromi: A temetésre vonatkozó egyházfegyelem... (i. m.) 49-5I, 87-88.

47 A bulla kritikai kiadása: DHA 1. 352-353 (I29. szám). A továbbiakban is az itt közölt szöveget használom, noha a szakirodalomban természetesen az I992. évi kritikai kiadása előtt más közlésből idéztek. Az egyöntetűség szempontján kívül ez azért is megengedhető, mert a kiadások között lényegi eltérés nincsen.
} 
A bullának a temetkezésre vonatkoztatott része egy igen hosszú, többszörösen összetett mondat: Latisclauus si quidem bone memorie Ungarorum rex ad honorem Dei et sanctorum apostolorum Petri et Pauli in memoriam sancti confessoris Aegydii Semichensem fundavit ecclesiam et eam per manum Odilonis felicis memorie predecessoris vestri monasterio Beati Aegydii, cui auctore Deo presides, obtulit, ubi et eius corpus venerabile requiescit, hanc nimirum oblationem pro animarum salute perpetratam nos largiente Deo Apostolice Sedis auctoritate firmamus, cui vestrum Flauiane Vallis cenobium ab eodem sancto Aegydio in salarium datum agnoscitur. ${ }^{48}$

Fordításban a következőképpen hangzik: Minthogy László, a magyarok jó emlékű királya Isten, valamint Szent Péter és Pál apostolok tiszteletére, Szent Egyed hitvalló emlékére alapította a somogyi egyházat, és azt boldog emlékü elődöd, Odiló keze által felajánlotta Szent Egyed monostorának, melynek Isten segítségével az élén állsz, és ahol az ő tisztelendő teste is nyugszik, ezt a lelkek üdvére tett felajánlást mi Isten meghagyásával és az Apostoli Szék tekintélyével megerősítjük, tudván, hogy Flavia-völgyi rendházatokat ugyanazon Szent Egyed adományozta az Apostoli Széknek.

Ennek az összetett mondatnak a lényegi eleme az a helyhatározói mellékmondat (ubi et eius corpus venerabile requiescit, azaz: „ahol az ő tisztelendő teste is nyugszik"), amely egy bizonyos holttest nyugvóhelyét jelöli, és nyilvánvalóan egyértelműen kívánta azt meghatározni. A szövegben össze nem keverhetően két, temetkezésre alkalmas egyházi intézmény szerepel, továbbá három elhunyt személy: Szent László király, Odiló saint-gilles-i apát, valamint a két egyházi intézmény azonos védőszentje, Szent Egyed.

Kérdés tehát, hogy melyik helyszínre vonatkozik a helyhatározói mellékmondat, hol temették el azt a bizonyos holttestet, és ki volt ez a személy. Mátyás és Baumgarten olvasata szerint Szent László teste nyugodott Somogyvárott. Ők a holttest kifejezést a mondatban tőle igen távol említett László királlyal és a somogyi egyházzal kapcsolták össze. Ehhez azonban arra volt szükség, hogy bizonyos közbülső, „zavaró” elemeket kihagyjanak a mondatból.

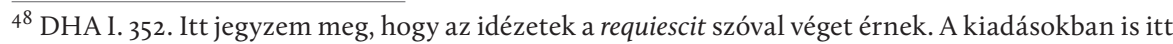
pontot szoktak tenni, holott a következő rész szerves tartozéka az előbbinek.
} 
Kipontozásos technikával szinte közvetlen kapcsolatot létesítettek a somogyi egyház és a mellékmondat között: Latisclauus si quidem bone memorie Ungarorum rex ad honorem Dei et sanctorum apostolorum Petri et Pauli in memoriam sancti confessoris Aegydii Semichensem fundavit ecclesiam, ... ubi et eius corpus venerabile requiescit...

Azaz magyarul: Minthogy László, a magyarok jó emlékü királya, Isten, valamint Szent Péter és Pál apostolok tiszteletére, Szent Egyed hitvalló emlékére alapította a somogyi egyházat, ... ahol az ő tisztelendő teste is nyugszik...

A mondatot megcsonkító idézők nagyvonalúan eltekintettek attól, hogy az ubi és eius szavakat a kihagyott részben említett Szent Egyed-monostorra és annak alapítójára vagy néhai apátjára vonatkoztassák. Azt sem vették figyelembe, hogy a helyhatározói mellékmondatot megelőzi egy másik mellékmondat, amelyben a pápa a bulla címzettjéhez, a Szent Egyed-monostor Hugó nevű apátjához szól, mondván: „a monostor, melynek Isten segítségével az élén állsz”. Ez a rész pedig vitathatatlanul a francia monostorra utal, tehát erre a helyszínre és erre a szentre kell vonatkoznia az „ahol az ő tisztelendo" teste is nyugszik” mellékmondatnak. Mátyás és Baumgarten régi és újabb követői is ezzel az idézési technikával éltek. Egyedül Sörös Pongrác közölte a teljes szöveget, de tévesen más magyarázatot füzött hozzá. ${ }^{49}$

Az oklevél szövegének elemzése további érveket is ad a kezünkbe. A pápai bulla ugyanis a benne szereplő három személyt három különböző jelzővel illeti. László királyt jó emlékűnek, Odiló apátot boldog emlékűnek, Egyedet pedig szentnek írja, és Szent Egyed két fontos tevékenységéről is szót ejt. Egyfelől ő építtette a Flavia-völgyben a francia monostort, másfelől ő adta azt a Szentszék birtokába. ${ }^{50}$ Ezen érdemek mellé került harmadik elemként, hogy ott is temették el, tisztelendő teste ott nyugszik. A venerabile jelző ugyanis nem illik sem világi,

\footnotetext{
${ }^{49}$ BÉKEFI: A Balaton környékének egyházai... (i. m.) I93 (4. jegyzet); SöRös: Az elenyészett benczés apátságok... (i. m.) I5I-I52 (5. jegyzet). Korábbi gyakorlatával szakítva, legutóbb Bakay Kornél is megadta a teljes szöveget, de fordítására nem vállalkozott, és nézetét sem változtatta meg: BAKAY: Somogyvár. Szent Egyed-monostor (i. m.) 94-95. Vö. Solymosı: Egy tévedés nyomában (i. m.) 169-170.

${ }^{50}$ Vö. J[acques] Pycke: Gilles (Saint). In: Dictionnaire d'histoire et de géographie ecclésiastique. XX. t. Sous la direction de R[oger] AuberT. Paris, I984, I352-I356. hasáb.
} 
sem egyházi személy holttestére, de annál inkább egy szentnek, azaz jelen esetben Szent Egyednek a földi maradványaira..$^{51}$

A mondat egyetlen helyes értelmezése az, hogy Szent Egyed nyugszik a francia monostorban, miként sírja ott ma is látható. A pápa azért idézte fel Szent Egyed tevékenységét és nyughelyét, hogy megerősítse a francia monostor fennhatóságát a somogyvári apátság felett, és kifejezze Szent Egyed és a két apátság, valamint a Szentszék szoros kapcsolatát. Erről és nem másról szól a bulla fontos mondata. ${ }^{52}$ Szent László királyt a váradi székesegyházban temették el, a somogyvári apátságban sohasem volt királysír.

\section{A KULTUSZ KEZDETEI}

A kultusz kialakulásáról találóak Gerics József (1931-2007) éppen Szent László kapcsán kifejtett gondolatai: „A szentként való tiszteletet a csodahit kialakulása általában meg szokta előzni, és a szentté avatáshoz megkívánt fama sanctitatisnak fontos elemét alkották a szentté avatandónak már előzetesen tulajdonított csodajelek. Éppen ezért a szentté avatás szorgalmazói már az eljárás megindításakor birtokában kellett, hogy legyenek olyan rendkívüli tettekről szóló híreknek is, amelyeket alkalmasnak tartottak a tiszteletben részesítendő személy szent voltának az alátámasztására. A szentként való elismertetés esélyei annál nagyobbak voltak, minél több és rendkívülibb cselekedetre vonatkozó hírt produkáltak. A szentté avatási eljárás egyik feladata volt azután az ilyen információk egyházi szempontból való hitelre méltóságának az elbírálása, megrostálásuk, a köztük való válogatás. A szentté avatás ténye természetesen még szélesebb körökben és most már hivatalosan terjesztette a kanonizált személy tiszteletét, és ilyen módon a neki tulajdonított csodák hírét meg is sok-

${ }^{{ }^{I}}$ A számos példából néhányat idézünk Burchardus wormsi püspök XI. elején összeállított joggyűjteményétől III. Ince pápa I2I5. évi okleveléig. Patrologiae cursus completus. Series Latina. Ed. Jacques-Paul Migne. I-CCXXI. Parisiis I844-I865, I40. köt. 558ab hasáb, I43. köt. 646c, 789a hasáb, 217. köt. 24Ia hasáb.

${ }^{52}$ Koszta László módosított valamit korábbi nézetén, de nem zárta ki azt a lehetőséget, hogy a királyt az általa alapított somogyvári monostorban temették el. KoszTA László: Bencés szerzetesség egy korszakváltás határán. Egyházpolitikai viták a II-I2. század fordulóján. Századok I46 (20I2), 294-300. Eredeti felfogása ugyanezzel a címmel jelent meg a bencésekről szóló tanulmánykötetben: Örökség és küldetés (i. m.) l. 78-82. Bírálatát lásd SolymOsı: Egy tévedés nyomában (i. m.) I7o. 
szorozhatta, de a tiszteletnek és a csodák hírének nem a szentté avatás szokott a kiindulópontja lenni. A szentté avatás rendszerint csak hivatalos elismertetése volt a bizonyos keretek között már meglevő kultusznak. Ebben a tekintetben maga a kisebb Legenda is eligazít, amikor világosan megkülönbözteti a László szentté avatása előtt és után keletkezett csodahíreket.”’3

A szentként való elismertetés esélyei annál nagyobbak voltak, minél több rendkívüli cselekedetre vonatkozó hír terjedt el az adott személyről.

Szent Lászlót sokan ismerték: a főpapok, a főurak, azon egyházi intézmények papjai, szerzetesei, amelyeket ő alapított, vagy adománnyal gazdagított. Ennél szélesebb körben is ismert volt. Szabolcson ro92-ben ő elnökölt az ország valamennyi világi előkelője, az egész papság és a nép tanúskodása mellett tartott zsinaton. ${ }^{54}$ Halála után a jótéteményeit élvező egyházi intézmények liturgikus keretben, kötelező módon megemlékeztek róla, hogy biztosítsák a király túlvilági boldogulását. A vele harcoló katonák felidézték harci élményeiket és benne a király szerepét, alkalomadtán meséltek róla, továbbadták emlékeiket. Az egyházi és világi előkelők az ország kormányzásában szerzett tapasztalataikat őrizték és vitték tovább. De mindebből az alapvetően egyedi élményanyagból az elhunyt uralkodó országos tisztelete aligha formálódott volna ki.

A kultusz kialakulásához szükséges alkalmas hely a váradi székesegyház volt, ahol a királysírnak meghatározó szerepe lett a kultusz kibontakozásában és továbbfejlődésében. ${ }^{55} \mathrm{~A}$ temetés volt az első esemény, amely alkalmat adott arra, hogy a különböző élményekkel, tapasztalatokkal bíró személyek találkozzanak egymással.

53 Gerics József: Krónikáink és a Szent László-legenda szövegkapcsolatai. In: Középkori kútföink kritikus kérdései. Szerk. Honváth János - Székely György. Budapest, I974, I28; újabb kiadásban: GERıCs József: Egyház, állam és gondolkodás Magyarországon a középkorban. (METEM Könyvek, 9.) Budapest, 1995, 200.

${ }^{54}$ ZávodszKy Levente: A Szent István, Szent László és Kálmán korabeli törvények és zsinati határozatok forrásai. (Függelék: A törvények szövege.) Budapest, I904, I57. Vö. Bolla Ilona: A jogilag egységes jobbágyosztály kialakulása Magyarországon. (Értekezések a történeti tudományok köréből, új sorozat, I0о.) Budapest, 1983, 43.

${ }^{55}$ Vö. TöRök József: Szent László a középkori magyarországi liturgiában. In: Athleta Patriae. Tanulmányok Szent László történetéhez. Szerk. Mezey László. Budapest, I980, I39; Ernő Marosı: Der heilige Ladislaus als ungarischer Nationalheiliger. Bemerkungen zu seiner Ikonographie im I4-I5. Jh. Acta Historica Artium Hungariae 33 (1987-I988), 215. 
Pontosan nem tudjuk, hol halt meg László király. ${ }^{56}$ A Legenda kocsi-csodájából ítélve biztosan mondhatjuk, hogy nem Váradon. De a temetés (depositio) I095. július 29-én a váradi székesegyházban volt. ${ }^{57}$

A távolságtól függően a holttest ideszállítása több-kevesebb napot vett igénybe. Útközben lovon vagy gyalog sokan csatlakoztak a látványos gyászmenethez, és Váradig kísérték a királyt utolsó útjára. A koporsó előtt feltehetően egy vagy több lovat vezettek, hogy a templomi szertartás során, amikor a gyászmisében elérkezik az adományok átadásának az ideje (offertorium), felajánlják őket az egyháznak..$^{88}$ Útközben sok mindenről beszélhettek, de leginkább az elhunyt uralkodóról. A váradi püspök és papság körmenettel vonult a közeledő gyászmenet elébe.59

A székesegyházba messze nem fért be mindenki. Az egyetemes egyház régi gyakorlata szerint a koporsót a főoltár elé helyezték. Könnyen lehetséges, hogy a koporsóval együtt vitték a király ezüst csatakürtjét és bárdját a székesegyházba, és mindkettő ekkor lett annak tulajdona. ${ }^{60}$ A csatakürt ottlétéről van kora újkori forrás. ${ }^{61}$ A nagy bárd birtoklásának az I557-ben készült leltár mellett tárgyi

\footnotetext{
${ }^{56}$ KÁDÁR Tamás: Az Árpád-házi uralkodók. Fons I9 (20I2), 75-76. Golso fia István pap misekönyvének 1363 előtt készült naptárában ugyan június 27-nél szerepel egy későbbi bejegyzés (Ladislai Regis Vngarie in czolnpurch), amelyből arra következtettek, hogy a király Zólyomban halt meg. Ez azonban nem bizonyítható. Mollay Károly: Középkori soproni naptárak. Soproni Szemle i6 (I962), 4. Sz., I5-I6. Erre az adatra épül az a megfogalmazás, hogy io95. július 25-én (!) Zólyom várában halt meg a király. BALOGH: Varadinum (i. m.) Il. 24. Mollay Károly nézetét nem fogadta el, és a misekönyv helynevét Budával, pontosabban Óbudával azonosította ZolnAy László: Buda sacra a szentek Budája. In: Uö: Az elátkozott Buda - Buda aranykora. Budapest, I982, 55I-555. Ezúton is köszönöm Szentmártoni Szabó Gézának, hogy felhívta a figyelmemet ezekre az adatokra.

${ }^{57}$ A I4. századi váradi és zágrábi statútumok nem egységesek: július 29. hol a temetés (depositio), hol az elhalálozás (obitus) napjaként szerepel bennük. Bunyitay: A váradi káptalan... (i. m.) 6, 8, Io, 6o; Documenta Trans. (i. m.) 683, 684, 685, 706; Joannes Bapt. Tkalčıć: Monumenta historica episcopatus Zagrabiensis. Il. Zagrabiae I874, I, 3. Vö. SRH I. 203, 205, 209. A saint-gilles-i apátság I2. századi halottas könyvének bejegyzése, az I524. évi váradi zsinati határozatok régi gyakorlatot őrző ünneplistája alapján egyértelmű, hogy ez a nap a temetés napja volt. Winzer: $S$. Gilles (i. m.) 376; JACZkó Sándor: A késő középkori hazai zsinati határozatok ünneplistái. In: Arcana Tabularii. Tanulmányok Solymosi László tiszteletére. Szerk. BÁrÁNy Attila - Dreska Gábor - Szovák Kornél. I-Il. Budapest-Debrecen, 20I4, I. 23I-232; JACZKó Sándor: A váradi egyház I524. évi zsinati határozatai. Budapest, 2016, 58-60, 230.

${ }^{58}$ A korábbi lovas temetkezés szokása helyébe lépett a ló felajánlása az egyháznak. Solymosı: Egyházi és világi... (i. m.) 554-555, 561.

${ }^{59}$ Magyar Anjou legendárium (i. m.) XLIV/20. kép.

${ }^{60}$ Vö. KarÁcSONYı: Szent László... (i. m.) IO2.

${ }^{61}$ KNAUZ Nándor: Régi egyházi ékszerek. Magyar Sion I (I863), 7II-7I2; PóR Antal: A pozsonyi társas-káptalani egyház leltára ı605-ből. Történelmi Tár, I885: 774. Vö. BALOGH: Varadinum (i. m.) Il. I30, I34.
} 
bizonyítéka is van. ${ }^{62}$ Nevezetesen a váradi káptalan I29I-ben készített nagyobbik pecsétnyomója, amelynek lenyomatain (6. kép) az uralkodó jobb kezében nem a szokásos jogar, hanem a bárd, Szent László attribútuma látható (7. kép). ${ }^{63}$

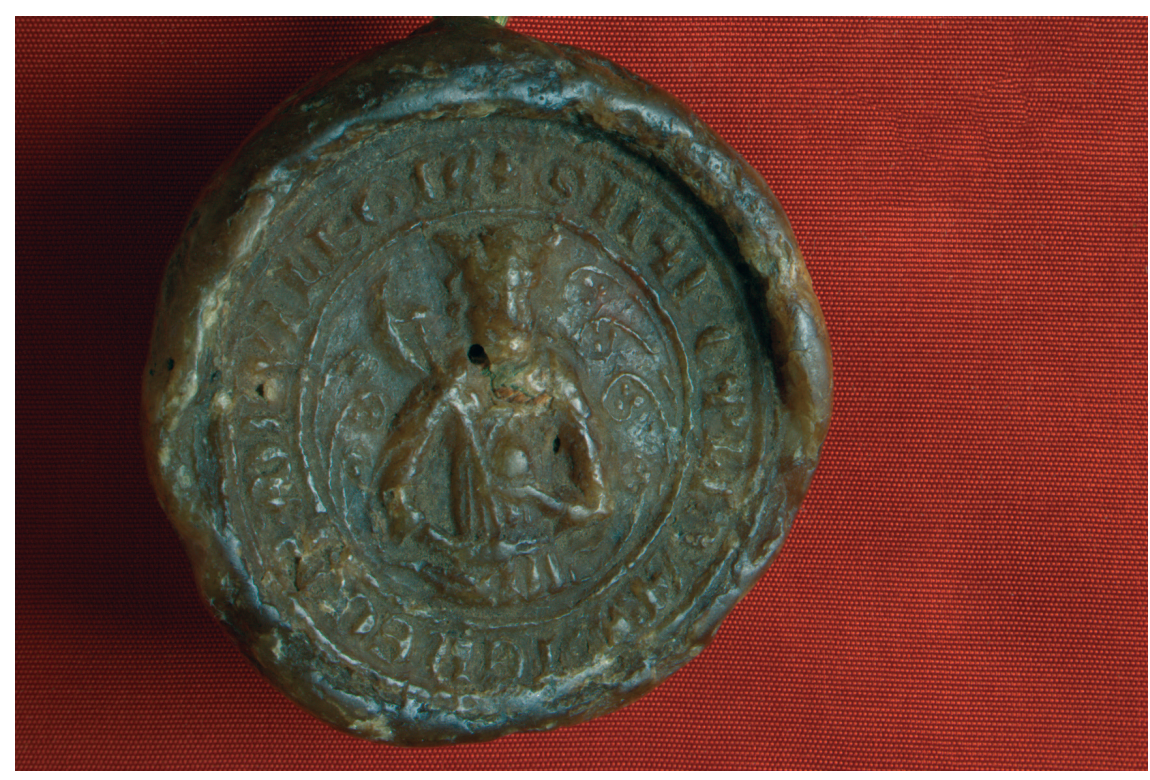

6. kép: A váradi káptalan I29I-ben készített nagyobbik pecsétnyomójának lenyomata I338-ból (Magyar Nemzeti Levéltár Országos Levéltára Diplomatikai Levéltár 3I7I/I.)

${ }^{62}$ MiKó Árpád - MolNÁr Antal: A váradi középkori székesegyház kincstárának inventáriuma (1557). Müvészettörténeti Értesítő 52 (2003), 305, 307, 317 (351. tétel). Ezúton is köszönöm Mikó Árpádnak, hogy az adatra felhívta a figyelmemet.

${ }^{63}$ Bunyitay: A váradi káptalan... (i. m.) 23-24; Documenta Trans. (i. m.) 692-693. Vö. Balogh: Varadinum (i. m.) I. I4-I5. TAKÁCs Imre: A magyarországi káptalanok és konventek középkori pecsétjei. Budapest, I992, 94-98. Az I29I-ben készült pecsétnyomó legjobb lenyomatát I338-ból őrizte meg egy oklevél. Magyar Nemzeti Levéltár Országos Levéltára Diplomatikai Levéltár 3I7I. A királyt ugyancsak bárddal ábrázolják a bázeli egykori karthauzi kolostor (ma Waisenhauskirche) üvegablakán, amely i4Io táján Kanizsai János esztergomi érsek megbízásából készült. SzenTmÁrTONi Szabó Géza: Cs. Szabó László és a XV-XVI. századbeli magyar emlékek Bázelban (Szent László, Kanizsai János, Szegedi Kis István). Irodalomismeret I6 (2005), 4. sz., 27-29 (kép: 28). 


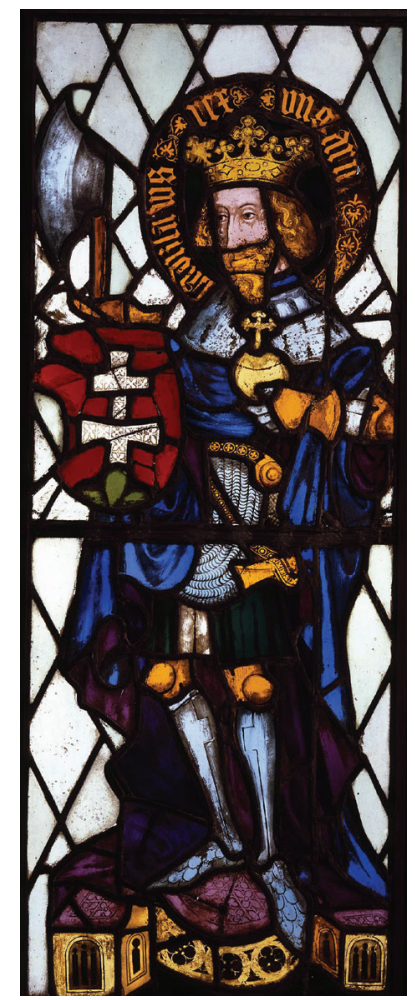

7. kép: Szent László király képe a bázeli karthauzi templom üvegablakán. Készült Kanizsai János esztergomi érsek megbízásából I4ı körül (a felvétel Szentmártoni Szabó Géza tulajdona)

Az egyetemes egyház régi gyakorlata szerint a koporsót a főoltár elé tették, és megkezdődött a halotti szertartás (officium defunctorum), majd a holttest jelenlétében (presente cadavere, presente corpore) elmondták a gyászmisét, a gyászbeszédet, és végül a király tetemét a székesegyházban eltemették. A temetési szertartás minden bizonnyal a jelenlevők lakomájával ért véget. ${ }^{64}$

\footnotetext{
${ }^{64}$ Karl Josef MERK: Die messliturgische Totenehrung in der römischen Kirche. Zugleich ein Beitrag zum mittelalterlichen Opferwesen. I. Teil. Stuttgart, I926, 9-15, 90; Hans LenTZE: Begräbnis und Jahrtag im mittelalterlichen Wien. Zeitschrift der Savigny-Stiftung für Rechtsgeschichte $(=Z R G) 67$, Kan. Abt. 36 (I950), 329-330; Arnold AngenendT: Theologie und Liturgie des mittelalterlichen Toten-Memoria. In: Memoria. Der geschichtliche Zeugenswert des liturgischen Gedenkens im Mittelalter. Hg. v. Karl Schmid und Joachim Wollasch. (Münsterische Mittelalter-Schriften, 48.) München, I984, 79-I99, különösen I7I-I74, I85-I87.
} 
A temetés 7. és 30. vagy 9. és 40. napján is mondtak gyászmisét. ${ }^{65}$ Ezeknél azonban sokkal fontosabb esemény volt a temetés évfordulója (anniversarium). ${ }^{66}$ Az évfordulós napokon az általános liturgikus gyakorlat szerint az alapító király túlvilági boldogulásáért rendszeresen mutattak be gyászmisét, melyet szintén étkezés követett. ${ }^{67} \mathrm{Az}$ évfordulós mise alkalmával körmenetben felkeresték az elhunyt sírját, hogy ott elvégezzék az elöírt szertartást (8. kép). ${ }^{68}$

\footnotetext{
${ }^{65}$ Solymosi: Egyházi és világi... (i. m.) 552-554.

${ }^{66}$ Az évfordulós megemlékezések első magyarországi írásos bizonyítéka Guden Szent László-kori adománylevelében olvasható. A végrendelkező úgy intézkedett, hogy a veszprémi Szent Mihály-székesegyháznak adott paloznaki javakból a kanonokok refectionem per singulos annos haberent et memoriam anime mee tenerent. GUTHEIL Jenő: Veszprém város okmánytára. Oklevelek a veszprémi érseki és káptalani levéltárakból (IOO2-I523). Kiadásra előkészítette KREDICs László. A kézirat kiadásának előkészítésében közreműködött Érszegi Géza és Solymosı László. Szerk. HermanN István. (A Veszprémi Egyházmegye Múltjából, I8.) Veszprém, 2007, 2I; DHA l. 225-226. Az idézett részlet értelmezésére lásd Solymosi: Hozott-e törvényt... (i. m.) 229-23I.

${ }^{67}$ Merk: Die messliturgische Totenehrung... (i. m.) IOI-IO2; Lentze: Begräbnis und Jahrtag... (i. m.) 335-336, 350-35I.

${ }^{68}$ A 12. század végi Pray-kódex szerint in anniversariis mortuorum dum exeunt cum processione ad sepulchrum alicuius defuncti pulsantibus omnibus signis cantent hunc psalmum: Miserere mei deus. Az Országos Széchényi Könyvtárban (= OSZK) őrzött kódex elérhető digitális formában: https:// mek.oszk.hu/I280o/r2855/html/index.html; vonatkozó oldal: hu_bi_mnyı_0332.jpg. Vö. Policarpus RADó: Libri liturgici manu scripti bibliothecarum Hungariae et limitropharum regionum. Primae partis editio revisa et aucta cui et toti adlaboravit Ladislaus Mezey. Budapest, 1973, 75.
} 


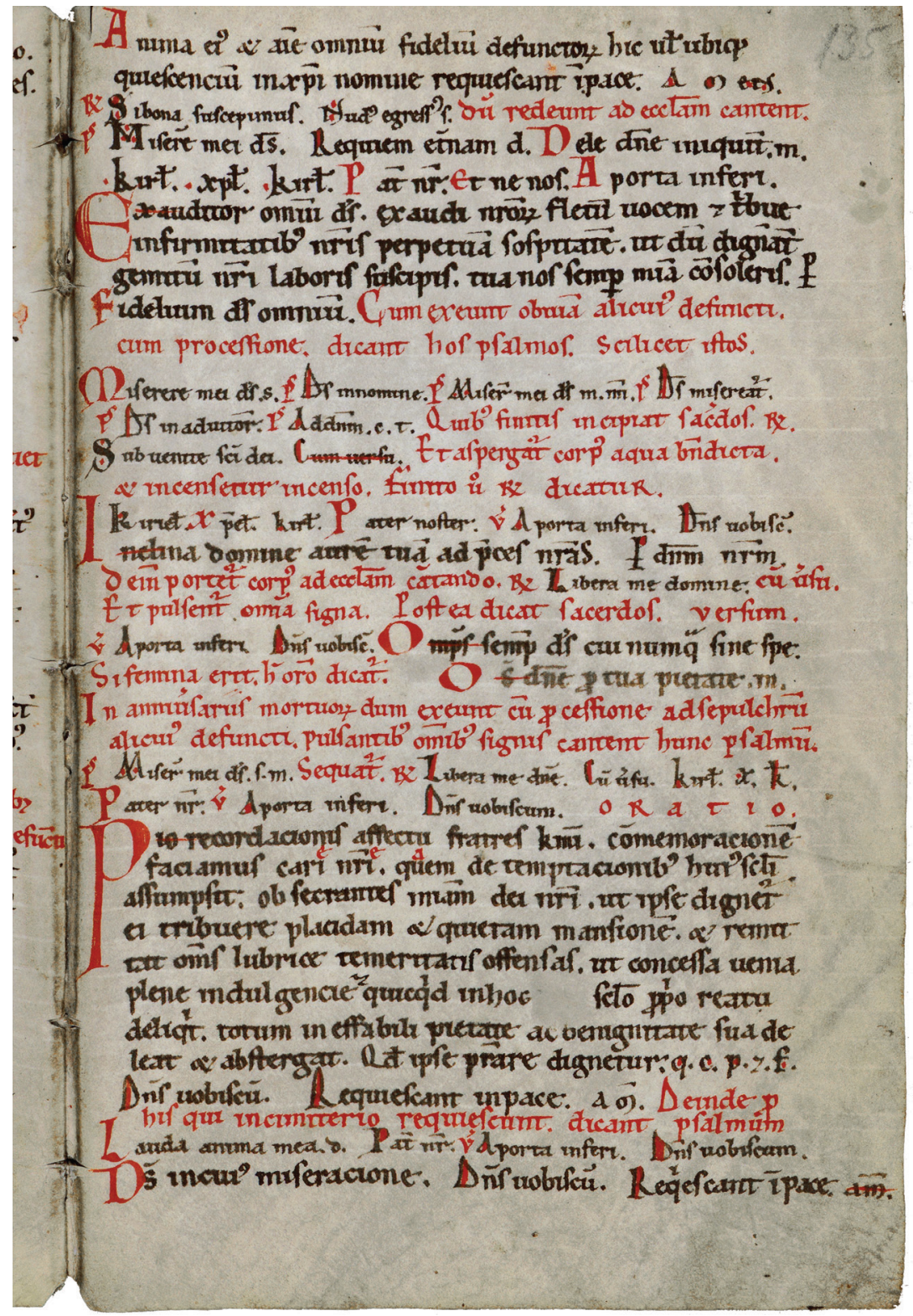

8. kép: Az évfordulós mise liturgiája a Pray-kódexből (Országos Széchényi Könyvtár, MNy I.; hu_bi_ mnyI_0332.jpg) 
Minden év július 29-én az évfordulós misén és a sírhoz kapcsolódó szertartáson nemcsak a székesegyház papsága vett részt, hanem Várad lakói, a környékbeliek és mások is. A hívők a többi ünnepnapon és egyéb alkalmakkor is felkereshették a sírt, amely rövid idő alatt zarándokhellyé vált. A sírt az ünnepeken égő gyertyával ékesítették. ${ }^{69}$

A király túlvilági boldogulását szolgáló liturgikus cselekmény, a róla való megemlékezés nem csupán a szavak szintjén valósult meg, hanem szorosan kötődött a földi maradványokat őrző sírhoz is. Erre másutt nem volt mód. Ezért lett Szent László kultuszának központja a váradi székesegyház, nem pedig a zágrábi székesegyház vagy éppen a somogyvári monostor, noha alapítójuk szintén ő volt, és az évfordulós gyászmisét itt is megtartották, akárcsak Saint-Gilles-ben, ahol a halottaskönyv szerint Szent László király mellett Péterről, a somogyvári monostor első apátjáról és a Somogyvárott zarándokként megforduló Ill. (Ferdeszájú) Boleszló lengyel fejedelemről is megemlékeztek. ${ }^{70}$

Jól mutatja Várad fontosságát a Legenda is. Fehérvár futólagos említése mellett Váradon kívül egyetlen magyarországi település sincsen benne megnevezve. A csodás események többsége is Váradhoz kötődik. A székesegyházban imádkozott éjjel a király, amikor az őt megleső szolga (cubicularius) szerint csodás módon a levegőbe emelkedett (levitatio). ${ }^{71}$ A kocsi-csoda Váradra vezette a temetési menetet. A többi csoda a váradi temetéskor vagy később a sírnál történt.

A király szentségének a híre (fama sanctitatis ipsius audita) a sírhoz vonzotta a gyógyulásért könyörgő híveket.7² Mint láttuk, Valter váradi püspök II3O táján a királysírt vonta be istenítélet jellegü ítélkezésébe. ${ }^{73}$ Rajtuk kívül a Legenda

\footnotetext{
${ }^{69}$ Joachim lovag és felesége, Anglia asszony iı99-ben végrendeletileg gondoskodtak arról, hogy az ünnepnapokon sírjuk fölé kárpit kerüljön, és legyen elég viasz, sőt ilyenkor egy asszonynak a sírnál kellett állnia. Veszprém Város Okmánytára. Pótkötet. Supplementum ad Monumenta civitatis Veszprimiensis (I000-I526). Összeállította Érszegı Géza - Solymosı László. Szerk. HermanN István, a szerkesztésben közreműködött KarLıNSzky Balázs, PeTrık Iván. (A Veszprémi Egyházmegye Múltjából, 20.) Veszprém, 2010, 58, 59. Kanizsai Dorottya 1525-ben végrendeletében sírja fölé két kárpitot adományozott, hogy ne legyen fedetlen, és két réz gyertyatartó vásárlásáról intézkedett, hogy sírjánál gyertyákkal világítsanak. KELÉNYı Borbála: Késő középkori magyar fö- és köznemesi női végrendeletek (I440-I526). PhD-értekezés, kézirat. Budapest, 2016, 79, I76-I77.

${ }^{70}$ WinZer: S. Gilles (i. m.) I70 (Péter), I99 (Boleszló), 376 (László).

${ }^{71}$ SRH II. 519-520.

${ }^{72}$ SRH II. 522-524. Az idézett latin részlet az 524. oldalon.

${ }^{73}$ SRH II. 524-525.
} 
a király életéből egyetlen csodás történetet örökített meg, amely nem kapcsolódott konkrét helyhez, nevezetesen azt, amikor a király sajátos módon gondoskodott éhező seregének ellátásáról.74 Nem kétséges, hogy a Legenda ősváltozatát a szentté avatás előtt Váradon írták.75 Ott is egészítették ki az II92-ben és nem sokkal utána a sírnál történt csodás eseményekkel. ${ }^{6}$

Érthető, hogy a kultusz kibontakozása és alakulása elválaszthatatlanul öszszeforrott a földi maradványokat rejtő sírral és a székesegyház papjaival, akiknek kötelességük és érdekük volt a kiemelkedő személyiség emlékének fenntartása és ápolása.

Különféle külső körülmények is befolyásolták, erősítették a kultusz alakulását, mint például az első, a második és a harmadik keresztes hadjárat seregeinek magyarországi átvonulása. ${ }^{77}$

A szentté avatáshoz vezető és egyre erősödő folyamatról forráshiány miatt keveset tudunk. ${ }^{78}$ Mindössze néhány adat idézhető fel. Már említettem, hogy Gallus Anonymus, lll. Boleszló lengyel fejedelem történetírója valamikor iııo táján urával együtt Magyarországon járt.79 Nem kétséges, hogy a királyi udvarban és másutt hallotta Szent Lászlóról azt a fontos vélekedést, amelyet méltónak ítélt arra, hogy gesztájában feljegyezze: „Mondják, soha nem volt Magyarországnak ilyen királya, és a földje sem volt oly termékeny utána."»o

\footnotetext{
${ }^{74}$ SRH 11.520.

${ }^{75}$ SRH 11. 5I3. (Bartoniek Emma megállapítása).

${ }^{76}$ SRH II. 525-527. Ezt a részt találóan a Legendához csatolt miraculum-fejezetnek nevezi MezeY László: Athleta Patriae. A korai László-irodalom kialakulása. In: Athleta Patriae. Tanulmányok Szent László történetéhez. Szerk. Mezey László. Budapest, I980, 40.

${ }^{77}$ Klaniczay: Az uralkodók szentsége... (i. m.) I63-165.

${ }^{78}$ KeRnY: László király szentté avatása... (i. m.) I75-I78; KLANıCZAY Gábor: A Szent László-kultusz kialakulása. In: Uő et al.: Nagyvárad és Bihar a korai középkorban. (Tanulmányok Biharország történetéről, I.) Nagyvárad, 2014 (= Nagyvárad és Bihar), I2-I6. Kerny Terézia minden tiszteletet megérdemlő és a további kutatásokat befolyásoló munkássága több forrást vett fel, mint ami elfogadható. Néhány törlendő közülük. ĺgy Könyves Kálmán király nem vésetett pénzei hátlapjára Ladislaus feliratot. Il. Géza király II58. évi oklevelében László király neve mellett a pius jelző nem bír különösebb jelentőséggel, hiszen ugyanez az oklevél Il. (Vak) Bélát a piissimus jelzővel illette. Mindezeken túl ráadásul az oklevél hamis. Az Árpád-házi királyok okleveleinek kritikai jegyzéke. Regesta regum stirpis Arpadianae critico-diplomatica. I. (IOOI-I270). Szerk. SzENTPÉTERY Imre. Budapest, I923-I930 (= Reg. Arp.), 93. szám.

79 BAGi: Gallus Anonymus... (i. m.) 38-39, 43, 221.

${ }^{80}$ Dicunt talem numquam regem Ungariam habuisse, neque terram iam post eum fructuosam sic fuisse. Gesta principum Polonorum (i. m.) 96.
} 
Itt nem egyszerűen arról volt szó, hogy a föld termékenységét összekapcsolták a nemrég elhunyt uralkodó személyével. A természeti jelenségeket ugyanis isteni megnyilvánulásnak tekintették.$^{8 \mathrm{I}}$ Isteni közreműködésről van szó: az ország Szent László földi érdemeinek égi elismerése okán lett termékeny, különösen, hogy Gallus Anonymus előzőleg éppen az uralkodó túláradó kegyességét (pietas) emelte ki. ${ }^{82} \mathrm{~A}$ király érdemei váltották ki az isteni megnyilatkozást Valter püspök említett ítélkezésében is, amikor a főpap a vita tárgyát képező ezüsttálat Szent László sírjára helyezte. A Legenda szerint a püspök azért folyamodott ehhez az eljáráshoz, mert a legteljesebb mértékben hitt abban, hogy a király érdemei kiváltják az isteni megnyilatkozást. ${ }^{83}$

Természetesen ez a felfogás nem csupán Szent László esetében érhető tetten. A budai káptalan egyházában I2II-ben birtokügyben tüzesvas-próbát tartottak. Ez alkalommal Szent Péternek, a budai egyház védőszentjének érdemei által (per merita beati Petri principis apostolorum) nyilvánult meg az igazság (iustitia), és lett a pannonhalmi apátság a per nyertese. ${ }^{84}$

Hogy a kultusz Valter püspök idejében alapvetően a váradi egyház belügye volt, jól mutatja Felicián esztergomi érsek ítélkezése a Váradon tartott zsinaton. Az érsek döntése nyomán a zágrábi székesegyház birtokügyében II34-ben a váradi székesegyház oltáránál (super sacrum Waradiensis ecclesie) tett esküt a váradi kanonokok jelenlétében a zágrábi egyház három nemesebb (nobilior) embere. ${ }^{85}$ Ennek alapján a zágrábi püspökség lett a per nyertese. Valter püspök ítélkezésével

\footnotetext{
${ }^{8 \mathrm{I}}$ VeSzPRÉmy László: Az invesztitúra harcok királyképe német földön és Magyarországon. (László és Salamon propagandája és annak utóélete). Arrabona 46 (2008), I. sz., 43. Vö. Georg SCHEıbELREITER: Der Regierungsantritt des römisch-deutschen Königs (I056-II38). MIÖG 8I (I973), 23-24; Peter Brown: A szentkultusz kialakulása és szerepe a latin kereszténységben. Budapest, I993, II9. Tartózkodóbb álláspontot képvisel Gerics: Krónikáink... (i. m.) I29-I3I; újabb kiadásban: Uő: Egyház, állam és gondolkodás... (i. m.) 200-203; Gerics József - LADÁNYı Erzsébet: Szent László „csodás” tettei krónikáinkban. Magyar Könyvszemle II7 (200I), 26-28; KLANiczay Gábor: Szent László „csodás” tettei krónikáinkban. Magyar Könyvszemle II7 (200I), 402-404; Uő: A Szent László-kultusz kialakulása (i. m.) I2.

${ }^{82}$ Az urával szemben elfogult Gallus Anonymus Szent László trónra lépéséről azt írta, hogy Boleszló in sede Wladislauum, sicut eminentem corpore, sic affluentem pietate collocavit. Gesta principum Polonorum (i. m.) 96.

${ }^{83}$ A Legenda szövege szerint a püspök de meritis beati regis certissime confidens per sententiam iudiciariam decrevit. SRH II. 525.

${ }^{84}$ A pannonhalmi Szent-Benedek-rend története. I. Szerk. ErdÉlyı László. Budapest, I902, 62I. Vö. uo. 62I-623.

${ }^{85}$ CAH 45-46 (I4. szám). Aligha kétséges, hogy a Szűz Mária tiszteletére emelt főoltárnál volt az eskü. BALOGH: Varadinum (i. m.) Il. 22.
} 
szemben Szent László sírjának itt nem volt semmi része a peres eljárásban, noha a I3. század elején több alkalommal itt tettek esküt. ${ }^{86} \mathrm{Az}$ II34. évi oklevél ugyan rögzítette, hogy László király az isteni kegyelem sugallatára (divina gratia inspirante) alapította meg a zágrábi püspökséget, továbbá szokatlan és megkülönböztetett módon a nobilissimus jelzővel illette az uralkodót, de hallgatott arról, hogy az ítélkezésben bármilyen módon közreműködött volna.

Az esküt rögzítő II34. évi ítéletlevél alapján feltételezhető, hogy Valter püspök ítélkezését is egykorúan feljegyezték, valamilyen formában megörökítették. ${ }^{87}$ Az elbeszélés olyan elemeket tartalmaz, mint például a püspöknek parancsot adó király (Il. István) és apjának (Könyves Kálmán) megnevezése, ami valamilyen jogbiztosító iratra vall. ${ }^{88}$ Akárhogy volt is, abban aligha kételkedhetünk, hogy a fontosabbnak ítélt csodás eseményeket egykorúan vagy közel egykorúan leírták, s nem bízták a múlékonynak tartott emlékezetre. ${ }^{89}$

A hit az isteni közreműködésben már a temetéskori első csoda alkalmával megmutatkozott. Egy vétkes a sírnál leborulva a király irgalmasságához könyörgött a gyógyulásáért. Csodás gyógyulását a legendaíró azzal magyarázta, hogy Isten a szentté avatáshoz szükséges eljárást szem előtt tartva (necessarium itaque deus beatificandi modum observans) megajándékozta Szent Lászlót azzal, hogy mindenkinek, aki hozzá fohászkodik, isteni segítséget adjon..$^{\circ \circ}$ Ez a megfogalmazás egyértelművé tette, hogy a kultusz célja a király szentté avatása volt, és ehhez Isten közreműködése biztosította a szükséges csodákat.

\footnotetext{
${ }^{86}$ A Váradi jegyzőkönyvben I6 alkalommal szerepel eskü, ezek közül hétszer a sírnál (super sepulchrum sancti Ladislai regis), egyszer pedig a sírnál és az ereklyéknél (super sepulchrum et reliquias sancti regis Ladislai) kellett az esküt letenni. Ezeket az esküket I2I6 és I235 között tették le. Regestrum Varadinense examinum ferri candentis ordine chronologico digestum, descripta effigie editionis a. 1550 illustratum sumptibusque capituli Varadinensis lat. rit. Curis et laboribus Joannis KarÁcsonYı et Samuelis Borovszky. Budapest, 1903 (= Reg. Varad.), I6I, I66, 229, 230, 315, 340, 356, 387. szám. A forrás digitális elérhetősége: Váradi Jegyzőkönyv - Regestrum Varadinense - The Varad Register (I208-I235). Szerk. Solymosı László - Szovák Kornél. A szövegkiadás Szovák Kornél munkája. CD-ROM. Budapest, 2009 .

${ }^{87}$ Ez a feljegyzés döntően azért nem maradt ránk, mert megőrzése feleslegessé vált, mihelyt szövege a Legenda része lett.

${ }^{88}$ Rex itaque Stephanus, Colomanni filius hanc causam Walthero, Waradiensi episcopo legittimo fine terminandam commisit, qui de meritis beati regis certissime confidens, per sententiam iudiciariam decrevit. SRH II. 524-525.

${ }^{89}$ A váradi középkori írásbeliségről összefoglalóan lásd Szovák Kornél: A váradi írásbeliség hagyománya. In: Nagyvárad és Bihar (i. m.) I29-I46.

${ }^{90}$ SRH Il. 524.
} 
Mivel a váradi papi közösség is tudta, mi kell a szentté avatáshoz, elkészítették a szükséges életrajzot (vita).9플 Ennek első része Szent László erényekben gazdag tevékenységét mutatta be, szinte csodák nélkül, hiszen mindössze két rendkívüli eseményt tartalmazott (az ima közbeni felemelkedést és az éhező sereg ellátását), míg második része a király halála utáni (post mortem) csodajeleket vette számba. ${ }^{92}$

A kultuszt ápoló és tápláló váradi székesegyház püspöke és papsága végül elérte Ill. Béla királynál, Jób esztergomi érseknél és a többi főpapnál, hogy megtegyék a szükséges lépéseket a szentté avatás ügyében. A királyi udvar támogatta az elképzelést. ${ }^{93} \mathrm{~A}$ keresztény uralkodó magától értetődően a kezdeményezés élére állt.

\section{A KIRÁLY SZENTTÉ AVATÁSA}

A I2. század második felében formálódott ki az az eljárás, amely századokra meghatározta a szentté avatás menetét. A létező gyakorlat szerint ennek három eleme volt. Először az érdekeltek kérvényben (petitio) kérték a pápától a kívánt személy szentté avatását. A kérvényhez csatolták az illető életrajzát (vita). Ezután következett a pápa vagy megbízottai vizsgálata (informatio) arról, hogy a javasolt személy valóban érdemes-e rá, hogy felvegyék a szentek közé. Végül a vizsgálódás

\footnotetext{
${ }^{91}$ A követelményeket III. Ince pápa II99-ben egy cremonai kereskedő szentté avatásáról szóló oklevelében a következőképpen fogalmazta meg: Licet autem iuxta testimonium Ueritatis sola finalis perseverantia exigatur ad sanctitatem anime in ecclesia triumphanti - quoniam, qui perseveraverit usque ad finem, hic salvus erit -, duo tamen, virtus videlicet morum et virtus signorum, opera scilicet pietatis in vita et miraculorum signa post mortem, ut quis reputetur sanctus in militanti ecclesia, requiruntur. Die Register Innocenz' III. I. Bd. I. Pontifikatsjahr, II98/99: Texte. Bearbeitet v. Othmar Hageneder und Anton Haidacher (= Reg. Inn.). (Publikationen der Abteilung für historische Studien des Österreichischen Kulturinstituts in Rom, Il/I.) Graz-Köln, I964, 762 (528. szám). Idézi: Erdő Péter: Szent Erzsébet kanonizációs eljárása és a korabeli egyházjog. Történelmi Szemle 58 (2016), 2I (I2I. jegyzet); újabb kiadásban: Uő: Jog az egyház hagyományában és életében. Budapest, 2016, 452. A pápai oklevél befejező része tömören fejezi ki a lényeget: Cum hec omnia tam de virtute morum quam virtute signorum ad favorem petitionis [...] concurrere videremus [...] ipsum sanctorum cathalogo duximus ascribendum. Reg. Inn. I. 764 (528. szám). Ezek az elvárások szinte kizárták, hogy a Krónikában leírt „csodás” történetek belekerüljenek az életrajzba.

${ }^{22}$ GeRıcs: Krónikáink... (i. m.) I28; újabb kiadásban: Uő: Egyház, állam és gondolkodás... (i. m.) 200. A király erényeire lásd SRH II. 5I8-5I9. Vö. GERICs: Krónikáink... (i. m.) II8-I24; újabb kiadásban: Uő: Egyház, állam és gondolkodás... (i. m.) I90-196.

${ }^{93}$ Nincsen semmi alapja annak a nézetnek, amely szerint a szentté avatás III. Béla király uralmának törvényesítését szolgálta volna. KRISTó Gyula: Szent László királyra emlékezve. Vigilia 57 (I992), 345. Csaknem két évtizedes uralkodás után a királynak erre aligha volt szüksége. Vö. TöRÖK József: A magyar föld szentjei. Debrecen, I99I, 70-7I; KLANıczay Gábor: Szent László kultusza a I2-I4. században. In: A középkor szeretete. Történeti tanulmányok Sz. Jónás Ilona tiszteletére. Szerk. KlanicZAY Gábor - NaGy Balázs. Budapest, I999, 366-367.
} 
pozitív eredményének ünnepélyes nyilvánosságra hozatala (promulgatio) zárta le az eljárást.94 Többnyire pápai oklevél (litterae), a 15. század közepétől pápai bulla tette közzé, hogy az illetőt beírták a szentek katalógusába. ${ }^{55}$ Vannak olyan esetek, amelyek forrásanyaga hiányos, az eljárás minden eleme nem adatolható. Közéjük tartozik Szent László magyar király (I077-I095) kanonizációja is. ${ }^{96}$

Szent László szentté avatásáról a Legenda mint befejezett tényről tudósít: II92ben testét dicsőségesen szentté avatták. ${ }^{97}$ A I2. század végi Pray-kódex kalendáriumában a szentté avatás következményeképpen június 27. a király földi maradványainak exhumálása (elevatio) ünnepnapjaként szerepel..$^{98}$ Ugyancsak ezzel az eseménnyel függ össze, hogy a Váradi jegyzőkönyv 34 év múltán fontos részletet örökített meg. Dénes mesterember (artificex) nyitotta fel az exhumálás alkalmával Szent László király sírját, és ezért III. Béla király felszabadította: leszármazottaival együtt örökös szabadsággal jutalmazta meg. Ezt a nem érdektelen információt azért jegyezték fel, mert a nevezetes Dénes mester fia I226-ban végrendelkezett: a Bihar megyei Besenyő település egyházára hagyta meghatározott feladatra rendelt szolgáját. 99

${ }_{94}$ Renate KLAuSER: Zur Entwicklung des Heiligsprechungsverfahrens bis zum I3. Jahrhundert. ZRG 7I, Kan. Abt. 40 (I954), 85-IoI, különösen 9I-96. Vö. Stephan KutTner: La réserve papale du droit de canonisation. Revue historique de droit français et étranger, IVe série, I7 (I938), I72-228, különösen 204-2I2; André VAUCHEZ: La sainteté en Occident aux derniers siécles du Moyen Ăge d'aprés les procés de canonisation et les documents hagiographiques. (Bibliothèque des Écoles françaises d'Athènes et de Rome, 24I.) Rome, 198I, 25-67.

${ }_{95}$ Otfried Krafft: Papsturkunde und Heiligsprechung. Die päpstlichen Kanonisationen vom Mittelalter bis zur Reformation. Ein Handbuch. (Archiv für Diplomatik, Schriftgeschichte, Siegel- und Wappenkunde, Beiheft 9) Köln-Weimar-Wien, 2005, 2, I033-I036.

${ }^{96}$ KUtTNer: La réserve papale... (i. m.) I74-I75 (5. jegyzet), I82 (3. jegyzet), 205 (I. jegyzet); KLANicZAY: Holy Rulers... (i. m.) I85-I86; KRAFFT: Papsturkunde und Heiligsprechung (i. m.) 208 (225. jegyzet). Vö. Klaniczay: Az uralkodók szentsége... (i. m.) I62.

${ }^{97}$ Dum igitur auctor universe creature hunc sanctum regem divine virtutis consortem esse tantis miraculis declarasset, anno domini millesimo centesimo nonagesimo secundo sanctum corpus eius gloriose est canonizatum. SRH 11. 525.

${ }^{98}$ A kódex naptárában június 27-hez írták: Eleuacio S. Ladizlay regis (hu_bi_mnyi_oo7o.jpg). A második húsvétmutató táblán a MCXCII évszám mellett a margón Eleuacio S. Ladizlay olvasható (hu_bi_ mnyı_0070.jpg; hu_bi_mnyı_0o83.jpg). Vö. RADó: Libri liturgici... (i. m.) 44, 49; SRH I. I2I.

${ }^{99}$ Tecus, filius Dionysii artificis, qui aperuit in elevatione sepulchrum Sancti Ladislai regis et a gloriossimo rege Bela dato pro eo artifice perpetua libertate donatus est cum omni generatione ab eo successura, sentiens dissolutionem sui corporis imminere, quendam servum suum, nomine Vrug, constituit dusnicum exequialem. Reg. Varad. 352. szám. 
A szentté avatás körülményeiről részletesebb, bár korántsem egykorú beszámolót olvashatunk Spalatói Tamás (I200/I-I268) művében. ${ }^{\text {I0o }}$ A spalatói főesperes az ókori Salona és a középkori Spalató (Split) város főpapjainak kívánt emléket állítani I266-ban befejezett történeti munkájában. Ebben Perugiai Bernát spalatói érsek (I200-I2I7) tevékenységének bemutatását a következő mondatokkal vezette be: „Ebben az időben a felséges férfiú, Béla, Magyarország királya elküldte bizalmas jegyzőit az Apostoli Székhez, és azt kérte Ince pápa úrtól, parancsolja meg, hogy boldog László király maradványait exhumálják, és illőbb helyen helyezzék el, továbbá rendelje el, hogy őt a szentek sorába iktassák. Kérésével egyetértett a pápa, és elküldött egy főtisztelendő férfiút, Gregorius de Crescentio bíborost, hogy a király akaratának illő módon tegyen eleget. Ekkor a bíboros, elvállalva az apostoli követséget, átkelt a tengeren, Dalmácia vidékére jött, és Trauban kötött ki. Mivel a tél zordsága még fenyegetett, az egész nagyböjt idején ugyanott akart maradni. Volt a kíséretében egy klerikus, a káplánja, név szerint Bernát, Toscana tartományból, Perugia volt a hazája, egy tudós és ékesszóló férfiú, magas termettel. Mivel őt gyakran küldték Magyarországra, ismert volt Béla király előtt, és olyannyira elnyerte az uralkodó és sok előkelő meg főpap kegyét, hogy a király maga bízta rá fiát, Imrét, hogy nevelje és oktassa. Midőn tehát a Magyarországra érkezett követ eleget tett követi megbízatásának, visszatért hazájába.”or

\footnotetext{
${ }^{100}$ Az itt nem tárgyalt késő középkori hazai forrás értelmezésére lásd KeRTÉsz Balázs: Megjegyzések Szent László kanonizációjához. Laskai Osvát második Szent László-sermójának forrásproblémája. Magyar Könyvszemle I22 (2006), 297-3I4; KLANiczAY: A Szent László-kultusz kialakulása (i. m.) I8-20.

${ }^{\mathrm{I}}$ Eo tempore illustris vir Bela Hungarie rex, missis apochrisariis ad apostolicam sedem, supplicavit domino pape Innocentio, ut iuberet reliquias beati Vladislavi regis sublevari et in loco decentiori componi ac ipsum in sanctorum cathalogo decerneret ascribendum. Cuius petitioni summus pontifex annuit et misit quendam virum reverendissimum Gregorium de Crescentio cardinalem, ut voluntati regie satisfaceret condecenter. Tunc cardinalis apostolica legatione suscepta transfretavit et venit in partes Dalmatie applicuitque Tragurium. Et quia yemis adhuc asperitas imminebat, voluit ibidem per totam quadragessimam comorari. Erat autem in comitatu eius clericus quidam capellanus ipsius, Bernardus nomine, de provincia Tuscie, patria Perusinus, vir litteratus et eloquens, statura procerrus. Hic quia frequenter in Hungariam fuerat missus, notus erat effectus regi Bele gratiamque ipsius et multorum principum et prelatorum Hungarie habebat, ita ut rex ipse filium suum Henricum ei nutriendum traderet et docendum. Cum ergo legatus in Hungariam prefectus legationis sue peregisset officium, ad propria reversus est. Thomae archidiaconi Spalatensis Historia Salonitanorum atque Spalatinorum pontificum. Latin text by Olga Perić. Edited, translated and annotated by Dalmir Karbić, Mirjkana Matijević Sokol and James Ross SweEney. (Central European Medieval Texts, 4.) Budapest - New York, 2006, 134-136 (cap. 23). Magyar fordításához vö. HoRváth János: A Gellért-legendák keletkezése és kora. In: Középkori kútfóink kritikus kérdései (i. m.) 158.
} 
A kutatás már régóta felhívta a figyelmet Spalatói Tamás tévedéseire. ${ }^{\mathrm{IO2}}$ Mindenekelőtt arra, hogy úgy szerepelteti Ill. Ince pápát (II98-I2I6), mint akinek része lett volna a szentté avatásban. A két évvel korábban elhalálozott IIl. Béla (II72-II96) természetesen nem fordulhatott kéréssel lll. Ince pápához (9. kép).

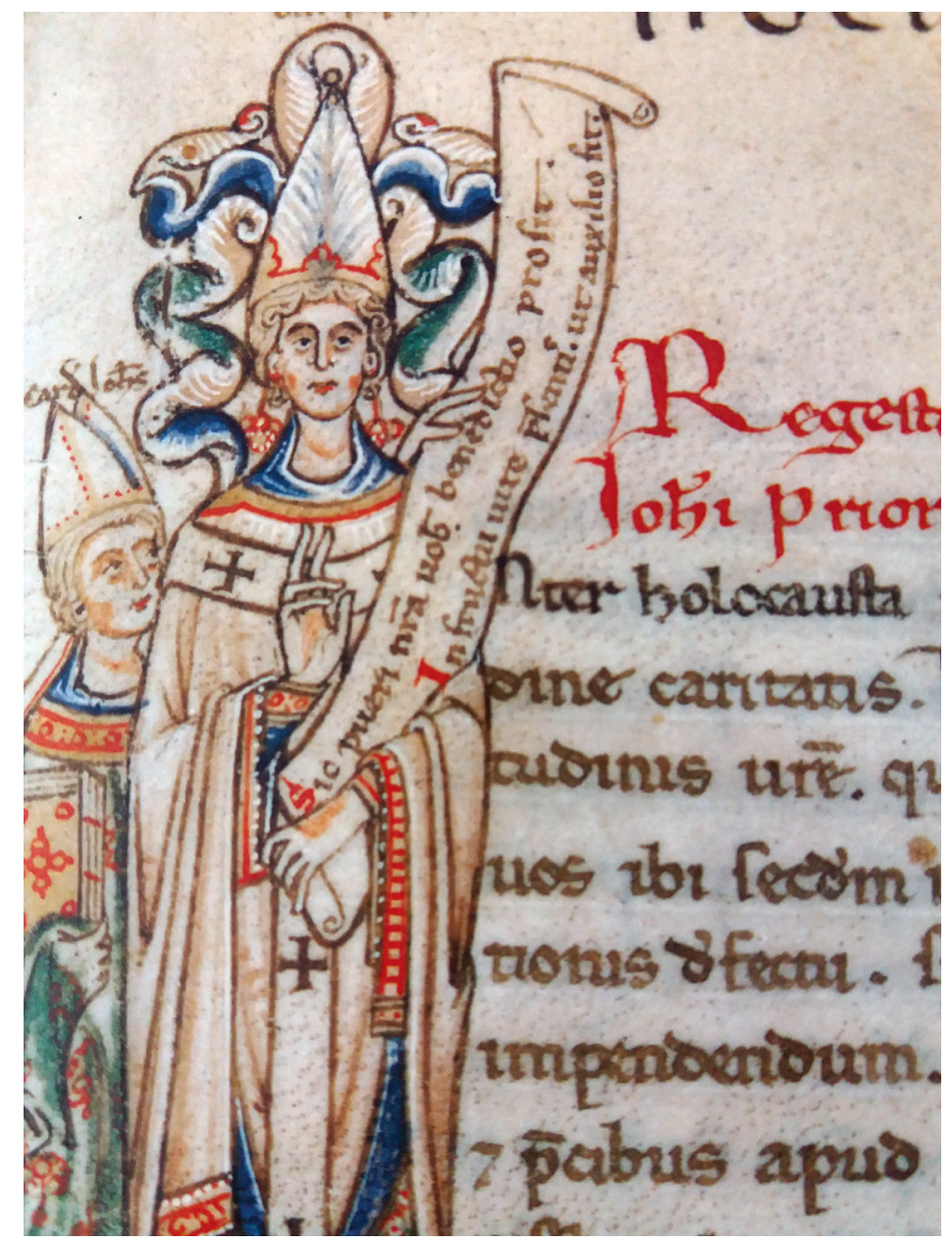

9. kép: IIl. Ince pápa képe. Alakos iniciálé az I203. évi pápai regisztrumkötetből (Archivio Apostolico Vaticano, Reg. Vat. 5. fol. $49^{\mathrm{r}}$ )

${ }^{102}$ Scriptores rerum Hungaricarum, Dalmaticarum, Croaticarum et Sclavonicarum. Cura et studio loannis Georgii SchWANDTNERI. III. Bibliopolae Vindobonensis I748, 567-568. 
A tévedés magyarázata, de nem mentsége, hogy Spalatói Tamás az idézett részlet előtt közvetlenül arról írt, hogy Miklós zárai választott érseket IIl. Ince pápa fosztotta meg fôpapi méltóságától. ${ }^{103}$ A tévedést javították is, Ill. Ince helyett automatikusan az őt megelőző III. Celesztin pápához (II9I-II98) kapcsolták a magyar király szentté avatását (Io. kép). ${ }^{104}$ Logikus a korrekció, de - mint látni fogjuk - nem ilyen egyszerü a megoldás.

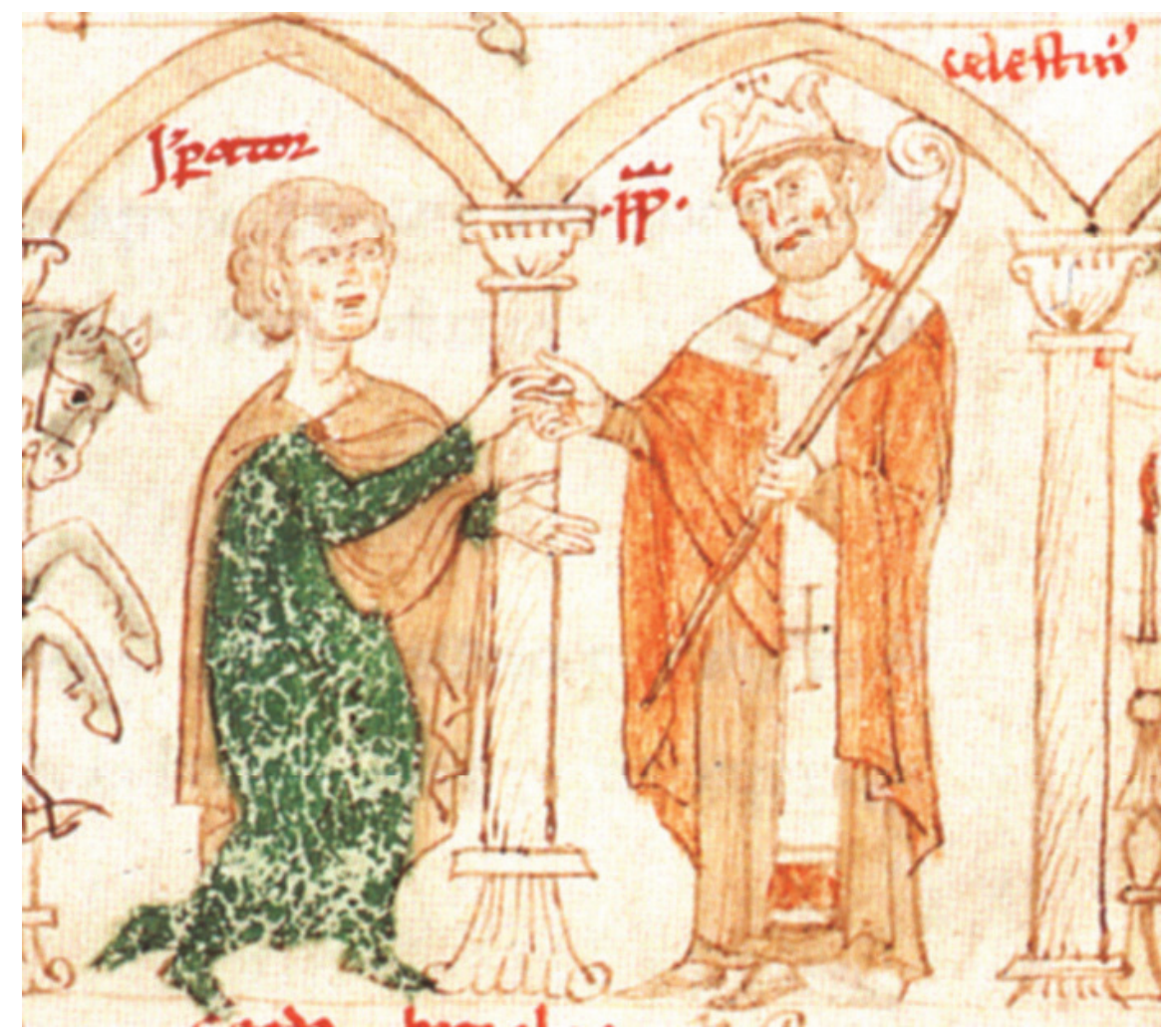

Io. kép: IIl. Celesztin pápa és VI. Henrik. Császárkoronázás II9I-ben Rómában. Részlet (Petrus de Ebulo: Liber ad honorem Augusti sive de rebus Siculis. Burgerbibliothek Bern, Cod. I20. II. fol. IO5 $^{\mathrm{r}}$ )

${ }^{103}$ Thomae archidiaconi Spalatensis Historia... (i. m.) I34.

${ }^{104}$ Bunyitay Vincze: A váradi püspökség története alapításától a jelenkorig. I-Ill. Nagyvárad, I883I884. IV. Debrecen, I935 (utánnyomás: Nagyvárad, I999-2002), I. 82; KARÁcsonY1: Szent László... (i. m.) 1 Ioo. 
Spalatói Tamás nemcsak a pápa, hanem a pápai legátus nevét illetően is tévedett. A római nemesi családból származó Gergely (Gregorius de Crescentio) pápai követ ugyan valóban létezett, sőt két rokon bíboros is ugyanezt a nevet viselte. Római címtemplomaik alapján jól megkülönböztethetők egymástól. Közülük az idősebbik járt Magyarországon, de ő is csak 1ll. Béla halála után. ${ }^{105}$

11l. Béla uralkodása alatt két pápai legátus kereste fel Magyarországot. ${ }^{106}$ Egyikük, Theobaldus püspök-bíboros Ill. Orbán pápa (II85-II87) követeként II86 végén vagy iı87 elején járt itt. Tevékenységét a pannonhalmi konvent, illetve a veszprémi káptalan számára kiadott keltezetlen oklevele tanúsítja. ${ }^{\mathrm{I07}} \mathrm{A}$ másik pápai legátus Gergely szerpap-bíboros (Gregorius de Sancto Apostolo, Dei gratia Sancte Marie in Porticu diaconus cardinalis) volt. Ö valóban kapcsolatba hozható Szent László király szentté avatásával.

Spalatói Tamás a pápai követ keresztnevét kétségkívül eltalálta. De ne legyünk igazságtalanok! Kutatási lehetőségei messze kisebbek voltak, mint a kései utódokéi.

Bármennyire is meglepő, a Bolognában tanult, művelt spalatói főesperes nem volt teljesen tisztában a szentté avatási eljárással. A ı2. század második felében létező gyakorlat szerint a földi maradványok exhumálása nem része, hanem rendszerint következménye volt a szentté avatásnak, amely a közzétételt követően valósult

\footnotetext{
${ }^{105}$ Werner Maleczek: Papst und Kardinalskolleg von II9I bis I2I6. Die Kardinäle unter Coelestin III. und Innocenz III. (Publikationen des Historischen Instituts beim Österreichischen Kulturinstitut in Rom, I/6.) Wien, I984, 90-92, I83-I84; Uő: Zwischen lokaler Verankerung und universalem Horizont. Das Kardinalskollegium unter Innocenz III. In: Innocenzo III - Urbs et Orbis. Atti del Congresso Internazionale, Roma 9-I5 settembre 1998. A cura di Andrea Sommerlechner. (Nuovi Studi Storici, 55. / Miscellanea della Società romana di storia patria, 44.) Roma, 2003, I34 (8. szám), I59-I60 (26. szám). Vö. BARABÁs Gábor: Gregorius de Crescentio bíboros élete és magyarországi legációi. In: Varietas delectat. A pápai-magyar kapcsolatok sokszínüsége a II-I4. században. Szerk. Kiss Gergely. (DeLegatOnline Könyvek, I.) Pécs, 20I9, 93-II5. Köszönöm a szerzőnek, hogy írását még évekkel megjelenése előtt rendelkezésemre bocsátotta.

${ }^{106}$ Barabás Gábor szerint János prenestei püspök-bíboros II9o-ben volt legátus Magyarországon. BARABás Gábor: A pápaság és Magyarország a I3. század első felében. Pápai hatás - együttmúködés érdekellentét. (Thesaurus Historiae Ecclesiasticae in Universitate Quinqueecclesiensi, 5.) Pécs, 2015, I8. Ez azonban a hivatkozott forrásmű (MALECzeK: Papst und Kardinalskolleg... [i. m.] 70-7I) alapján nem felel meg a valóságnak. János püspök jóval korábban, iI64-ben járt Magyarországon.

${ }^{107}$ Stephan Weiss: Die Urkunden der päpstlichen Legaten von Leo IX. bis Coelestin III. (I049-II98). (Forschungen zur Kaiser- und Papstgeschichte des Mittelalters, Beihefte zu J. F. Böhmer, Regesta Imperii, I3.) Köln-Weimar-Wien, I995, 288.
} 
meg előbb vagy utóbb. ${ }^{108}$ Spalatói Tamásnál fordított a sorrend: megfogalmazása szerint a király előbb az exhumálásra, majd a szentté avatásra kérte a pápát. Abban viszont nem tévedett, hogy az eljárásban a pápai legátus is részt vett.

Nos, mit tudunk Gergely legátusról, akinek valamilyen formában köze lehetett Szent László szentté avatásához?

A római családból származó Gergelyt Ill. Kelemen pápa (II87-II9I), Ill. Celesztin elődje nevezte ki szerpap-bíborossá. Római címtemploma a Sancta Maria in Porticu lett. Először II88. április 5-én, utoljára pedig I202. január I-jén szerepelt a pápai privilégiumok aláírói között. Legátusként járt Magyarországon. ${ }^{109} \mathrm{~A}$ kérdés az, hogy mikor és hányszor.

A válaszadáshoz kiindulópontként azt kell megnézni, hogy a bíborosi kinevezése és Ill. Béla halála közötti időszakban Gergely mikor volt hosszabb ideig távol a pápai kúriától, azaz mikor hiányoznak aláírásai a pápai bullákon. Eszerint először II89. február 20. és II9O. május 7., másodszor pedig II92. január II. és II92. november 22. között tevékenykedett legátusként. ${ }^{\text {IIO }}$

Mindjárt jegyezzük meg, hogy a két távollét két egymást követő pápa uralkodásához kapcsolódik. Az első Ill. Kelemen, a második meg Ill. Celesztin pápa idejében történt. Az utóbbit elődje halála napján, II9I. március 29-én vagy 30-án választották meg. ${ }^{\text {III }}$

A két hosszabb távollét önmagában csak lehetőséget ad a követi megbízatás feltételezésére. Szerencsére vannak egykorú okleveles adatok, amelyek bizonyítják, hogy Gergely legátusként kétszer járt Magyarországon. Keltezetlen oklevelében, amelyet Ill. Ince pápa regisztrumkötetéből ismerünk, éppen maga hivatkozik korábbi magyarországi követi tevékenységére (prius officium lega-

\footnotetext{
$\overline{{ }^{10} 8}$ Hitvalló Edward angol király kanonizációs levelét III. Sándor pápa II6I-ben állította ki, míg transzlációja II63-ban történt. Becket Tamás canterburyi érsek transzlációja I220-ban volt, noha III. Sándor pápa II73-ban vette fel a szentek katalógusába. GeRICs: Krónikáink... (i. m.) I3I; SOLYMOsi László: Magyar főpapok angliai zarándoklata I220-ben. Történelmi Szemle 55 (2013), 530.

${ }^{109}$ Maleczek: Papst und Kardinalskolleg... (i. m.) 93-94; Uő: Zwischen lokaler Verankerung... (i. m.) I34-I35 (Io. szám), I64-I67.

${ }^{\text {IIO }}$ Reg. Inn. I. 376 (4. és 7. jegyzet). Vö. Maleczek: Papst und Kardinalskolleg... (i. m.) 93 (253. jegyzet), 366-368.

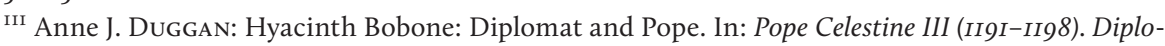
mat and Pastor. Eds. John Doran - Damian J. SMith. Farnham, 2008, I-2.
} 
tionis gessimus in Vngaria). ${ }^{\mathrm{II}}$ További két adat is vonatkozik erre az első útra. 11l. Celesztin pápa IIgI. december 20 -án megerősítette a szebeni prépostság alapítását. Jób esztergomi érsekhez intézett levelében megemlítette Gergely követ erre vonatkozó oklevelét (privilegium), amit akkor állított ki, amikor legátus volt (tunc apostolice sedis legatus). ${ }^{113}$ Magából a pápai oklevél keltezéséből is az következik, hogy csakis Gergely legátus első útjáról lehetett szó. Péter spalatói érsek IIg2. április r6-án Spalatóban kiadott ítéletlevele lezárta a traui püspök és a traui Szent Lőrinc-székeskáptalan közti vitát, és egyben megerősítette a bíboros e tárgyban hozott döntését, amely akkor született meg, amikor pápai követ volt Magyarországon. ${ }^{\mathrm{II}} \mathrm{Ez}$ az adat is az első úttal hozható kapcsolatba.

Gergely bíboros legátusként tehát bizonyíthatóan kétszer járt Magyarországon, sőt oklevelet is adott itt ki. ${ }^{\text {II }}$ Az első útja II89/9o-ben, a második pedig II92ben volt. Mindkét küldetés teljesítése viszonylag hosszabb időt, több hónapot vett igénybe.

A megbízatás tárgyáról néhány oklevél tájékoztat. Eszerint a legátus egyfelől Dél-Dalmáciában, közelebbről a spalatói egyháztartományban tevékenyke-

\footnotetext{
${ }^{\mathrm{II}}$ A legátus (Gregorius de Sancto Apostolo, Dei gratia Sancte Marie in Porticu diaconus cardinalism apostolice sedis legatus) oklevének szövegét III. Ince pápa II98. június I5-i megerősítő átírása tartotta fenn. Reg. Inn. 1. 375-377 (272. szám). Vö. Erdélyi Okmánytár. Codex diplomaticus Transsylvaniae. I. (IO23-I300). Bevezető tanulmánnyal és jegyzetekkel regesztákban közzéteszi JAKó Zsigmond. (A Magyar Országos Levéltár Kiadványai, Il/26.) Budapest, I997, I29 (22. szám), I30 (24. szám).

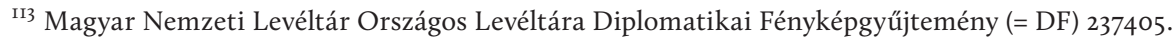
(Esztergomi Székesfókáptalan Magánlevéltára, 44-II-2) Kiadása: Monumenta ecclesiae Strigoniensis. I-II. Ed. Ferdinandus KNAuz. Strigonii I874-I882 (= Mon. Strig.), I. I4I-I42. Regesta pontificum Romanorum ab condita Ecclesia ad annum post Christum natum MCXCVIII. Ed. Philippus JAFFÉ. Editionem secundam correctam et auctam auspiciis G. Wattenbach curaverunt S. LOEWENFELD - F. KALTENBRUNNER - P. EwALD. I-II. 'Leipzig, I885-I888 (= JL), Il. 584, I6773-I6774. szám. Azért van két szám alatt, mert nem gondolhattak arra, hogy Fejér György egy oklevélből közlésében kettőt teremtett. Codex Diplomaticus Hungariae ecclesiasticus ac civilis. Studio et opera Georgii Fejér. Il. Budae I829, 276-277. Vö. Erdélyi Okmánytár (i. m.) I28-I29 (I9-2I. szám).

${ }^{\text {II4 }}$ Codex diplomaticus regni Croatiae, Dalmatiae ac Slavoniae. (Diplomatički zbornik kraljevine Hrvatske, Dalmacije i Slavonije.) Ed. T. Smičıklas. II-III. Zagrabiae I904-I905 (= SmičıkLas: Cod. dipl.), II. 253-255. Az érseki ítéletlevél, amely G(regorius) de sancto Apostolo, Dei gratia sancte Marie in Porticu diaconus cardinalis rendelkezését említi, a következőképpen végződik: apostolatus Celestini III. anno secundo, Gregorio de Sancto Apostolo tunc fungente legationis officio in regno Hungarie, serenissimo rege Bela eidem Hungarie necnon Croatie, Dalmacie Rameque feliciter imperante.

${ }^{115}$ Ezt azért kell hangsúlyozni, mert Gergely követ sem III. Kelemen, sem III. Celesztin pápa legátusai sorában és oklevéllistáikban sem szerepel a téma kézikönyvében. Weiss: Die Urkunden der päpstlichen Legaten... (i. m.) 290-320, 389-391.
} 
dett, ahol a traui püspök és a székeskáptalan perében járt el. ${ }^{116}$ Másfelől a Magyar Királyságban a szebeni prépostság ügyével foglalkozott. ${ }^{\mathrm{II7}}$

Il. Géza király (II4I-II62) lakatlan területet (desertum) adományozott Dél-Erdélyben a betelepülő szászoknak, akik Szebenben egyházi intézményt építettek. III. Béla kiváltságos prépostsággá tette ezt az intézményt, s erről hiteles okmányt (autenticum scriptum) állított ki.

Ezt az okmányt első útja idején (II89. február 20. és II90. május 7. között) oklevéllel Gergely legátus, majd IIl. Kelemen pápa is megerősítette. Végül III. Celesztin pápa is jóváhagyta a király intézkedését, bevezettette regisztrumába, és minderről IIgI. december 20-án tájékoztatta az esztergomi érseket. ${ }^{\mathrm{I} 8}$ Ez minden bizonnyal azért következett be, mert a kiváltságos királyi prépostságok nem a területileg illetékes megyéspüspök, vagyis az erdélyi főpap, hanem az esztergomi érsek joghatósága alá tartoztak.

Hamarosan értelmezési vita kerekedett a szebeni prépost és az erdélyi püspök között az említett királyi, illetve legátusi oklevélben szereplő desertum, vagyis pusztaság szó miatt. A prépost azt állította, hogy az összes szász telepes (Flandrenses) az ő egyházának van alávetve, míg a püspök azt mondta, hogy a ki-

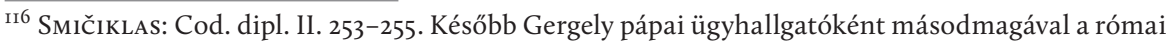
kúriában tárgyalta a spalatói érsek és a város papjainak ügyét. SMIčıKLAS: Cod. dipl. Il. 278-279; JL Il. 624, I7404. szám. Jóval Gergely halála után, I206-ban Ill. Ince pápa hivatkozott erre a tevékenységére megerősítő oklevelében. Smičıklas: Cod. dipl. Ill. 56-58. Vö. Árpádkori új okmánytár. Codex diplomaticus Arpadianus continuatus. Közzé teszi Wenzel Gusztáv. VI. Pest, I867, 309-310; Regesta pontificum Romanorum inde ab a. post Christum natum MCXCVIII ad a. MCCCIV. Ed. Augustus PotTHAST. I-II. Berolini I874-I875, I. 240-24I, 28II. szám; MALEczeK: Papst und Kardinalskolleg... (i. m.) 93. Itt említendő, hogy ismert Gergely bíboros keltezetlen oklevele, amelyet a spalatói klérushoz és néphez intézett Mihály fárai püspök ügyében. Ebben az oklevelében Gergely nem nevezi magát legátusnak. SMıčıkLAs: Cod. dipl. II. 325. A kiadás a forrást II99 nyarára datálja.

${ }^{117}$ A prépostság alapítását II89 nyarára vagy II90-re teszi Wolfgang GRANDJEAN: Die Anfänge der Hermannstädter Propstei im Spiegel päpstlicher Urkunden. In: Zur Rechts- und Siedlungsgeschichte der Siebenbürger Sachsen. (Siebenbürgisches Archiv, III/8.) Köln-Wien, I97I, 269. Mások II9I-re teszik az alapítást. F. RomHÁNyı Beatrix: Kolostorok és társaskáptalanok a középkori Magyarországon. [Budapest,] 2000, 45. Vö. THOROCZKAY Gábor: A szebeni prépostság történetének főbb kérdései a XIV. század közepéig. Fons I9 (2012), I. sz., 38-4I.

${ }^{\text {II8 }}$ Cum autem ecclesia Theuthonicorum Vltrasiluanorum in preposituram sit liberam [in]stituta, et eisdem, quibus [et alie] prepositure exempte, liber[tatis insignibus redimita, et eam] autentico scripto karissimus in Christo filius noster B(ela) illustri[s] rex Vngarie studuerit communire, quam etiam dilectus filius noster Gregorius, Sancte Marie in Porticu diaconus cardinalis, tunc apostolice sedis legatus privilegii sui munimine roboravit, et apostolica postmodum auctoritas confirmavit, eandem institutionem ratam habentes, precepimus nostri registri serie contineri perhenni memoria duraturam. DF 237405. (Esztergomi Székesfőkáptalan Magánlevéltára, 44-II-2.) Kiadása: Mon. Strig. I. I4I-I42. Az idézett rész uo. I4I.
} 
rály és a legátus értelmezése szerint csak azok tartoznak a prépostsághoz, akik a lakatlan területen telepedtek le. Az ügy végül a pápa, immár Ill. Celesztin elé került, aki Gergely bíborost bízta meg a jogvita rendezésével.

Gergely második magyarországi legációján tett eleget a pápa megbízásának. Veszprémben megkérdezte IIl. Béla királyt, aki mágnásai jelenlétében kijelentette, sem a prépostság alapításakor (tempore constitutionis prepositure), sem később nem állt szándékában, hogy minden szász a prépostságnak legyen alávetve. A prépostsághoz csak a pusztaságban letelepedett szászok tartoznak.

A legátus elfogadta a király értelmezését, és a préposttal szemben az erdélyi püspöknek adott igazat. A püspök gondoskodott a számára kedvező döntés megörökítéséről. Kérésére II98-ban Ill. Ince pápa (auctoritate apostolica) megerősítette és átírta a legátus levelét, amely így a pápa első regisztrumkötetében fennmaradt (II. kép). ${ }^{\text {II }}$

\footnotetext{
${ }^{119}$ Nos vero idem cum domino rege sentientes et eandem interpretationem habentes in animo, predictum verbum sic interpretamur, quod de nullis aliis Flandrensibus intelleximus nec alios prepositure supposuimus, nisi dumtaxat illos, qui tempore, quo ipsam preposituram constituimus, in illo tantum habitabant et erant habitaturi deserto, quod G(eisa) rex Flandrensibus prioribus concessit. Reg. Inn. I. 375-377 (272. szám). Az idézett rész uo. 377. Vö. Solymosı László: Veszprém korai történetének néhány kérdése. In: Válaszúton. Pogányság-kereszténység, Kelet-Nyugat. Konferencia a X-XI. század kérdéseiről. Szerk. KREDics László. Veszprém, 2000, I46.
} 


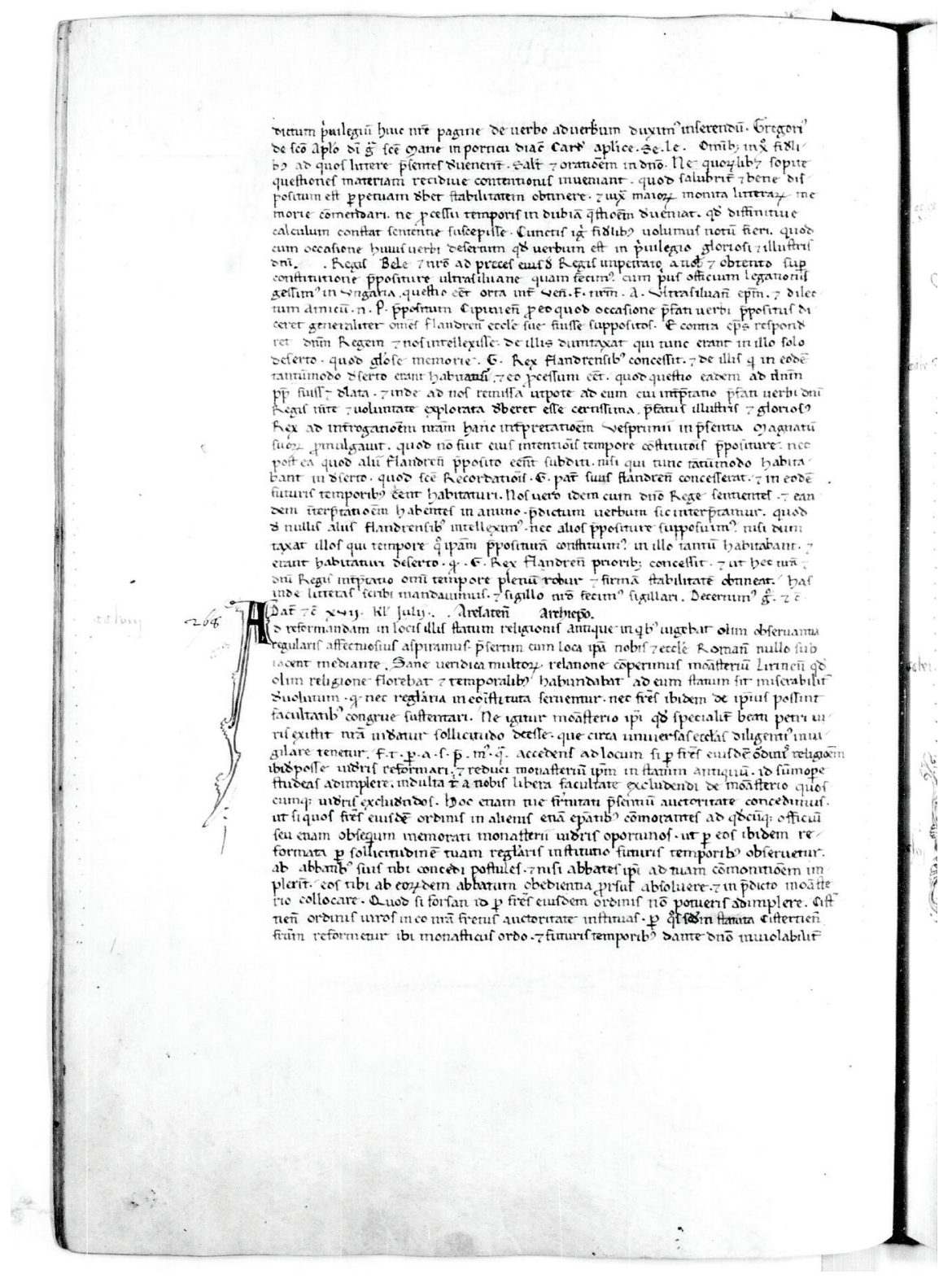

II. kép: Gergely legátus levele III. Ince pápa II98. évi átírásában (Archivio Apostolico Vaticano, Reg. Vat. 4. fol. $66^{v}$ ) 
A két legációval kapcsolatos okleveles forrásokban nem esik szó Szent Lászlóról és szentté avatásáról. A szebeni prépostság ügye azonban némiképpen összefügg vele, mivel Szent László lett az intézmény égi patrónusa. ${ }^{\mathrm{I} 2}$

Ugyanakkor nem valószínű, hogy Gergely legátus tevékenysége a spalatói egyháztartomány és a szebeni prépostság említett ügyeire korlátozódott volna. Ezeket ugyanis a pápai kúriában is elintézhették volna. A követ bizonyára tárgyalt a magyar királlyal a Ill. keresztes hadjáratban való részvételről is. De nem ez volt a fö feladata.

Gergely legátus küldetésének igazi célja László király szentté avatása lehetett. ${ }^{\text {I2r }}$ Mással nem tudjuk magyarázni, miért kellett alig négy év alatt kétszer is Magyarországon járnia. Az eseményeket a következőképpen rekonstruálhatjuk.

II88 végén vagy iI89 elején a főpapok, mindenekelőtt Jób esztergomi érsek és a váradi püspök támogatásával IIl. Béla király kérvényt nyújtott be Ill. Kelemen pápához Szent László szentté avatása ügyében. A kérvényhez minden bizonnyal Szent László legrégebbi, ma már ismeretlen őslegendájának a szövegét mellékelték. ${ }^{\mathrm{I} 22}$

A pápa Gergely bíborost bízta meg azzal, hogy megvizsgálja, teljesíthető-e a kérés. Gergely legátusként II89-ben Magyarországra jött, ahol Váradon és másutt tanúkat hallgatott ki. Visszatérte után, jelentése ismeretében, III. Kelemen pápa még Iıgo-ben vagy legkésőbb IIgI márciusának végén bekövetkezett halála előtt felvette a magyar uralkodót a szentek sorába, és erről oklevelet állított ki.

De az is lehetséges, hogy ezt a feladatot IIgI-ben (legkésőbb irg2 első napjaiban) már az új pápa, Ill. Celesztin végezte el. Az biztos, hogy Gergely bíboros már tőle kapta újabb legátusi megbízását. Második küldetése során, II92. június 27-én Gergely főcelebránsként részt vett Váradon az ünnepélyes szertartáson, amely az exhumálást követően a földi maradványok átvitelét (translatio) foglalta magában.

\footnotetext{
${ }^{120}$ F. RomHÁNYı: Kolostorok és társaskáptalanok... (i. m.) 45; MEző András: Patrocíniumok a középkori Magyarországon. (METEM Könyvek, 40.) Budapest, 2003, 216.

${ }^{\text {I2I }}$ Minden bizonnyal Szent László kortársának, János traui püspöknek a szentté avatási ügye is Gergely legátusi feladatai közé tartozott. Ana Marinković: Celestin III and Dalmatia. In: Pope Celestine III (i. m.) I85-I87. A jelek szerint a vizsgálat megtörtént, de szentté avatás nem lett belőle, életrajza I203-ban nyerte el végső formáját. Mindenesetre Spalatói Tamás írt János püspök traui tiszteletéről, szentségéről, de szentté avatásáról nem jegyzett fel semmit. Aligha hallgatta volna el, ha ez megtörtént volna. Thomae archidiaconi Spalatensis Historia... (i. m.) 76-77 (cap. I6), 154-I55 (cap. 24).

${ }^{122}$ Az elveszett őslegendára lásd Bartoniek Emma bevezetését. SRH II. 509-5II.
} 
Végeredményben a szentté avatást kinyilvánító pápai oklevél Gergely legátus két magyarországi küldetése között, vagyis IIgo. május 7. és II92. január II. között keletkezhetett, és kiadója a két pápa bármelyike lehetett. Akárhogy volt is, a szentté avatási eljárásban valamilyen formában mindkét pápának része volt. Ilyesmi máskor is előfordult. Kunigunda császárné szentté avatási eljárása II97ben kezdődött IIl. Celesztin pápa idején, és IIl. Ince alatt fejeződött be I20o-ban. ${ }^{123}$ Mivel a kanonizáció és az exhumálás az azt követő szertartással együtt időben olyan közel esett egymáshoz, és az utóbbi volt az ünnepélyes helyi esemény, a Legenda a kevésbé valószínű II92. évet tekintette a szentté avatás időpontjának.

A fenti gondolatmenettel kapcsolatban önkéntelenül is felvetődik a kérdés: Miért nincsen a szentté avatásnak okleveles nyoma? Miért nem maradt fenn erről pápai oklevél? A források hiányából nem szerencsés magát a tényt megkérdőjelezni. ${ }^{\mathrm{I24}}$ Inkább arra a kérdésre kell magyarázatot találni, miért nincsenek okleveles források.

Mind IIl. Kelemen, mind Ill. Celesztin pápa idejében készültek regisztrumkötetek, amelyekbe szokás szerint általában bemásolták a pápai kiadványok szövegét. Mint láttuk, mindkét pápa említett magyar vonatkozású oklevelével is ez történt. A két pápa regisztrumkötetei azonban megsemmisültek. ${ }^{\mathrm{I} 25}$ Ezért hiába kutatunk a Vatikáni Apostoli Levéltárban. Így csak azokról a pápai döntésekről van ismeretünk, amelyek a címzettek vagy mások levéltárában fennmaradtak.

Esetünkben azonban a címzettek levéltáraival sincsen szerencsénk. A szentté avatásról szóló pápai okleveleket Ill. Béla magyar királynak, Jób esztergomi érseknek, Elvin váradi püspöknek és a váradi klérusnak kézbesíthették. A középkori királyi és a váradi egyházi levéltár a tatárjárás, majd a török uralom

\footnotetext{
${ }^{\text {I23 }}$ Volkert Pfaff: Die innere Verwaltung der Kirche unter Papst Coelestin Ill. Mit Nachträgen zu den Papstregesten II9I-II98. Archiv für Diplomatik I8 (I972), 364.

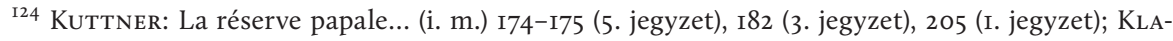
NiczAY: Az uralkodók szentsége... (i. m.) I62; Uő: Holy Rulers (i. m.) I85-I86; Uő: Szent László „csodás” tettei... (i. m.) 395-396; Krafft: Papsturkunde und Heiligsprechung (i. m.) 208 (225. jegyzet). Szent László szentté avatása kapcsán pápai oklevél és más megerősítő forrás hiányát hangsúlyozza a Legendák adataival szemben Michael Goodich: The Canonization Policy of Celestine III. In: Pope Celestine III (i. m.) 310.

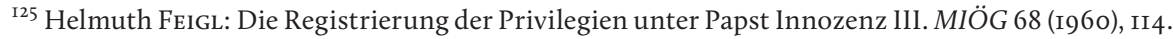
Félreértés szülhette azt a megfogalmazást, hogy Ill. Celesztin pápa „jól megőrzött regesztái” vagy „épségben fennmaradt regesztái” Szent László szentté avatásáról „semmiféle utalást nem tartalmaznak". Klaniczay: Szent László kultusza a I2-I4. században (i. m.) 367; Uő: Az uralkodók szentsége... (i. m.) I62; Uö: Holy Rulers... (i. m.) I85-I86. Vö. KraffT: Papsturkunde und Heiligsprechung (i. m.) 208 (225. jegyzet).
} 
alatt elpusztult. ${ }^{\mathrm{I26}} \mathrm{A}$ Prímási Levéltár ugyan gazdag anyagot tartalmaz, de itt is döntően azok az oklevelek maradtak meg, amelyek az érsek és a székesegyház jogaira vonatkoztak. Ilyen tartalmú okleveleket ebből az időszakból mindkét pápától őriznek Esztergomban, de szentté avatásról szólót nem. ${ }^{127}$

Az sem kedvezett az oklevelek fennmaradásának, hogy a szentté avatás jogilag lezárt ügy volt. Megtörténte után nem pereskedtek miatta, mint ahogy birtokügyekben számtalanszor megtették, szerencsés esetben oklevelek sokaságát hagyva az utókorra. Gondoljuk meg, ha Gergely legátus említett oklevele másolatban nem maradt volna meg Ill. Ince pápa regisztrumkötetében, akkor még annak sem lenne írásos bizonyítéka, hogy kétszer járt követként Magyarországon.

Végül a rekonstrukció szükségessé teszi Gergely bíboros szerepének tisztázását a szentté avatási eljárásban. Spalatói Tamás szűkszavúan csak annyit írt, hogy követi feladatát teljesítette (legationis sue peregisset officium). Ebbe az általános megfogalmazásba minden további nélkül belefér, amit eddig tulajdonítottunk neki, hogy a helyszínen kihallgatta a tanúkat, és felvette vallomásaikat, majd második küldetése alkalmával részt vett az exhumálást követő szertartáson.

A kérdés az, hogy volt-e ennél nagyobb szerepe Gergely legátusnak, nevezetesen rendelkezett-e különleges pápai felhatalmazással, amelynek birtokában ő avathatta szentté a magyar királyt Váradon. ${ }^{228}$ Ezzel a lehetőséggel nem számoltunk, s nem véletlenül.

${ }^{126}$ A Magyar Országos Levéltár. Szerk. Lakos János. Budapest, I996, II; Bunyitay: A váradi püspökség... (i. m.) IV. I25-I28.

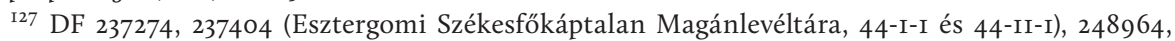
248965 (Prímási Levéltár, Archivum ecclesiasticum vetus, 4. és 5. szám). Kiadásuk: Mon. Strig. I. I35, I39, I40.

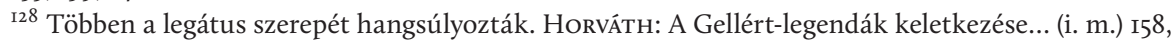
I6I; TöRöK: Szent László a középkori magyarországi liturgiában (i. m.) I38; Uő: Szent László szentté avatása. Müemlékvédelem 36 (1992), I97; ERDő: Szent Erzsébet... (i. m.) 7; újabb kiadásban: Uő: Jog az egyház hagyományában... (i. m.) 433. A legutóbb megjelent nézet szerint „László királyt iıg2-ben avatták szentté Váradon, IIl. Celesztin pápa beleegyezésével, akit a hazánkban immáron másodszor megforduló, ezúttal Dalmáciából érkező Gregorio de San Apostolo bíboros-követ képviselt”. THоROCZKAY Gábor: László király szentté avatása. In: Uő: Ismeretlen Árpád-kor. Püspökök, legendák, krónikák. Budapest, 20I6, I27. A legátusok pápai felhatalmazásáról lásd Jürgen PeTERsOHN: Die päpstlichen Kanonisationsdelegation des II. und I2. Jahrhunderts und die Heiligsprechung Karls des Großen. In: Proceedings of the Fourth International Congress of Medieval Canon Law (Toronto, 2I-25. August 1972). Ed. Stephan Kuttner. (Monumenta luris Canonici, ser. C, subsidia 5.) Città del Vaticano, I976, I63-206, különösen I72-I99. Vö. WeIss: Die Urkunden der päpstlichen Legaten... (i. m.) 284-285. 
Többévszázadosgyakorlatutánaszenttéavatásieljárásjogifeltételrendszerét viszonylag későn, a I3. század első évtizedeiben fogalmazták meg. A kánonjogi szabályozás a mindenkori pápának biztosított kizárólagos illetékességet a szentté avatásban. ${ }^{22}$ Az alapelvet Paulus Hungarus, a neves kánonjogász fogalmazta meg, mielőtt I22I-ben Bolognából hazatért volna Magyarországra: non debet venerari aliquis publice sanctus, nisi canonizetur ab ecclesia Romana. ${ }^{\mathrm{I} 30}$

Az idevezető folyamatban jelentős része volt lll. Celesztin személyének, aki pápasága előtt Hyacinthus Bubonis néven közel ötven éven át bíborosként és számos alkalommal legátusként is tevékenykedett. ${ }^{13 \mathrm{I}}$ Mint pápa (a magyar királyt nem számítva közéjük) öt személyt maga avatott szentté. Ezzel a teljesítménnyel Ill. Honorius (I216-I227) és IX. Gergely pápával (I227-I24I) együtt ő vezeti a középkori pápák szentté avatási listáját. Egyik esetben sem bízta a szentté avatást legátusára. ${ }^{\mathrm{I} 2}$ Sőt ragaszkodott ahhoz, hogy pápaként megerősítse egy korábbi eljárásának az érvényességét. II73 elején ugyanis legátusként ő nyilvánította szentté Rosendo püspököt, anélkül, hogy erre pápai felhatalmazást kapott volna.

IIl. Sándor (II59-II8I) pápa megbízásából Hyacinthus Bubonis kardinális, a későbbi IIl. Celesztin az ibériai félszigeten járt követségben, ahol szentté nyilvánította hitvalló Rosendo (907-977) püspököt, Dumio (Mondofiedo) egykori főpapját, és erről oklevelet állított ki. ${ }^{133}$ Ebből kiderül, hogy részletes vizsgálatot tartott, sok tanú igaz vallomásából és a püspök életrajzából (tum ex multorum relatione veridica tum ex ipsius vite scripture recitatione) tájékozódott a főpap tevékenységéről. A legendából kiírta életének fontosabb csodás eseményeit, majd a halála után történt csodákat. Ezeket megfontolva és León, Kasztília és Portu-

\footnotetext{
${ }^{129}$ KUTTNER: La réserve papale... (i. m.) I72-228; TöRÖK: Szent László a középkori magyarországi liturgiában (i. m.) I37-I39; ERDő: Szent Erzsébet... (i. m.) I-22; újabb kiadásban: Uő: Jog az egyház hagyományában... (i. m.) 425-452. Vö. Bernhard Schim melpFennig: Heilige Päpste - päpstliche Kanonisationspolitik. In: Politik und Heiligenverehrung im Hochmittelalter. Hg. v. Jürgen Petersohn. (Vorträge und Forschungen, 42.) Sigmaringen, I994, 73-78; KraffT: Papsturkunde und Heiligsprechung (i. m.) 2.

${ }^{\mathrm{I} 30}$ Idézi KutTner: La réserve papale... (i. m.) 204, 223 (Notabilia ad Comp. secundam).

${ }^{\text {I3I }}$ Maleczek: Papst und Kardinalskolleg... (i. m.) 68-70; Weiss: Die Urkunden der päpstlichen Legaten... (i. m.) 173-203, 207, 249, 383-387.

${ }^{132}$ Krafft: Papsturkunde und Heiligsprechung (i. m.) I73-2I3, különösen 208-209, 264-266, 309.

${ }^{133}$ Damian J. Smith: The Iberian Legations of Cardinal Hyacinth Bubone. In: Pope Celestine III (i. m.) 94-95.
} 
gália uralkodói, továbbá számos főpap, szerzetes és nemes kérésére úgy döntött, hogy a püspök földi maradványait illőbb helyre vigyék át, és őt szentként tiszteljék. Ezért megparancsolta a bragai érseknek és püspöktársainak, hogy tiszteletére ünnepnapot jelöljenek ki, és gondoskodjanak a test átviteléről. Egyúttal búcsúkiváltságot adományozott azoknak, akik az eseményen és a szent ünnepnapján megjelennek. Hogy ennek nagyobb foganatja legyen, három környékbeli püspököt bízott meg ennek kihirdetésével. A legátusi levélből egyértelműen megállapítható, hogy mindezt különleges pápai felhatalmazás nélkül tette. Hogy mi vitte rá erre a lépésre, azt megtudjuk a pápaként II95-ben kiadott okleveléből: a helyszínen szerzett tapasztalatán, meggyőződésén túl a hite. Mint írta, hitt abban (credidimus), hogy a szent életű püspököt be kell írni a szentek katalógusába, és szentként kell tisztelni.

Legátusi döntését nem kellett módosítania, de úgy érezte, hogy a formáját igen. Ezért Ill. Celesztin pápaként II95-ben megerősítette a több mint két évtizeddel korábbi szentté nyilvánításának érvényességét. ${ }^{34}$ Ennek alapján zártuk ki azt a lehetőséget, hogy lll. Celesztin pápa különleges megbízást adott volna Gergely legátusnak Szent László kanonizálására.

III. Kelemen pápáról nem mondhatjuk el ugyanezt, mivel a szentté avatást több alkalommal átruházta legátusára. ${ }^{135}$ De ennek itt nincs különösebb jelentősége, mert őt halála megakadályozta abban, hogy Gergely bíboros második küldetésére bármilyen felhatalmazást adjon. A két pápa eltérő gyakorlata a szentté avatás módjáról megengedi a feltételezést, hogy a magyar királyt szentté avató oklevelet Ill. Celesztin pápa állította ki, mégpedig nagy valószínűséggel IIgI-ben.

\footnotetext{
${ }^{134}$ Weiss: Die Urkunden der päpstlichen Legaten... (i. m.) I85 (37. szám), 202-203; KrafFT: Papsturkunde und Heiligsprechung (i. m.) 204-209. A két oklevél értelmező tanulmánnyal két kiadásban is elérhető. Antonio García y García: A propos de la canonisation des saints au XIle siècle. Revue de Droit Canonique, I968, I8: 3-15, forrásszöveg: 5-9; Uő: La canonizacion de San Rosendo de Dumio. In: Uő: Estudios sobre la canonistica Portuguesa medieval. Madrid, I976, I57-I72, forrásszöveg: I67-I72. Vö. JL II. 617, I7287. szám. (A francia nyelvű cikk megszerzését Diera Diána szívességének köszönöm.)

${ }^{3} 35$ Krafft: Papsturkunde und Heiligsprechung (i. m.) I62-I72; Jürgen Petersohn: Jubiläumsfrömmigkeit vor dem Jubelablaß. Jubeljahr, Reliquientranslation und „remissio” in Bamberg (II89) und Canterbury (I220). Deutsches Archiv für Erforschung des Mittelalters 45 (1989), 38-39.
} 
Az elveszett oklevél tartalmi-szerkezeti felépítése nyilvánvalóan a hasonló pápai kiadványok mintáját követte. ${ }^{136}$

\section{A SZENTTÉ AVATÁS KÖVETKEZMÉNYEI}

A szentté avatás, majd az azt követő transzláció II92. június 27-én és e nap kötelező ünneppé nyilvánítása a kultusz kiteljesedését hozta magával.

A halotti liturgiával összefonódó kultuszt a szent liturgikus tisztelete váltotta fel. Ehhez liturgikus szövegek kellettek. Az átvitel ünnepére összeállították (bizonyára még nem teljesen végleges formában) a szent király tiszteletére mondott miséhez szükséges liturgikus szöveget (officium). ${ }^{137}$ A könyörgések az idézett mottóval összhangban utalnak a király bünös voltára, de egyben azt is kifejezik, hogy Isten megbocsátott neki, és az örökkévalóság dicsőségében részesítette az uralkodót (I2. kép). ${ }^{138}$

\footnotetext{
${ }^{136}$ Két közel egykorú oklevelet ismerünk IIl. Ince pápától. Az egyik oklevél II99. január I2-én, míg a másik I20o. április 3-án készült. Az előbbi a cremonai Homobonus, az utóbbi Kunigunda császárné szentté avatásáról szól. Reg. Inn. I, 76I-764 (528. szám); André VAUCHEZ: Saint Homebon de Crémone, "père des pauvres " et patron des tailleurs. Vies médiévales et histoire di culte. (Subsidia hagiographica, 96.) Bruxelles, 20I8, 5-I5, II6-I22; Jürgen Petersohn: Die Litterae Papst Innocenz' III. zur Heiligsprechung der Kaiserin Kunigunde (I200). Jahrbuch für fränkische Landesforschung 37 (I977), 20-25.

I37 TöRöK: Szent László a középkori magyarországi liturgiában (i. m.) I43-I44, I58-I59.

${ }^{138}$ Deus, qui beatum Ladizlaum regem nostrum [a szó kivakarva] et confessorem tuum miro miserationis modo delinquentem ad veniam et iustum transtulisti ad gloriam, presta, quesumus, ut quem rectorem habuimus in terris, eum modo protectorem sentiamus in celis. [...] Deus, qui beato Ladizlao regi et confessori tuo post terrene dignitatis fastigium eternitatis lauream contulisti, concede propicius, ut qui eius merita venerantur in terris, ipsi quoque in gloria consocientur in celis. OSZK. hu_bI_mnyI_02I7.jpg. Vö. Töвöк: Szent László a középkori magyarországi liturgiában (i. m.) I43, I58. A miseimádságban említett bűnös király és a szentté avatási eljárás vizsgálati részének (informatio) összefüggése vitatott. GeRıcs József: Legkorábbi gesta-szerkesztéseink keletkezésrendjének problémái. (Értekezések a történeti tudományok köréből, új sorozat, 22.) Budapest, I96I, I04-I07; Mezey: Athleta Patriae. A korai László-irodalom... (i. m.) 46; Gerics József - LADÁNYı Erzsébet: A Szent László-ábrázolás forráskérdései legendájában és a krónikában. Magyar Könyvszemle II8 (2002), I-2; KLANiczAY: A Szent László-kultusz kialakulása (i. m.) 20. A téma részletes tárgyalását lásd KertÉsz: Megjegyzések Szent László kanonizációjához (i. m.) 303-314.
} 


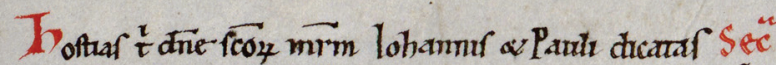

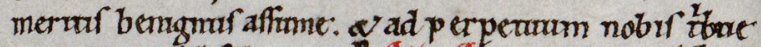
proutente fubfidurm. I Co 5 amplimur dine

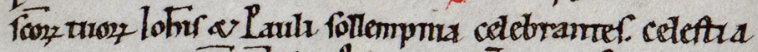

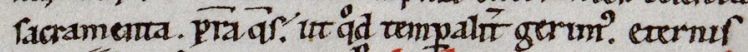
ganduif conkquanur: I S. La dizlar regif.

- $\vec{s}$ qua beam ladizlarm regem a confer forem taum muro muferauome in detunquentem

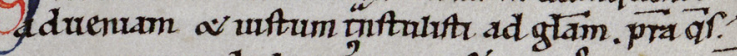
ut quem recrorem habum untertr!' earm in ptectorefencuanur moethr. 1 Ser

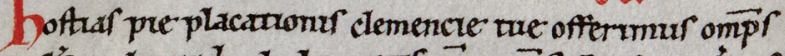

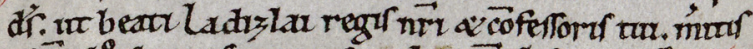

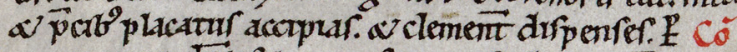

S antamenta dine fatuarua fumenter. clemencia ruam

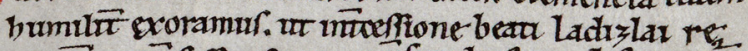

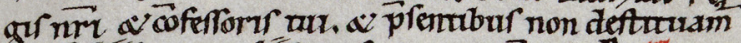

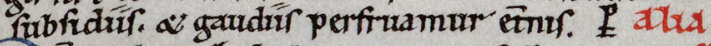

A) $s$ qu bearo Ladryla regr aconfeffor tuo orffa

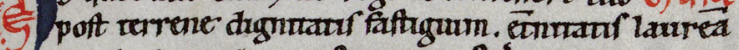

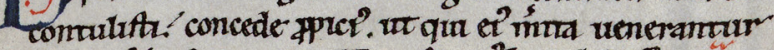

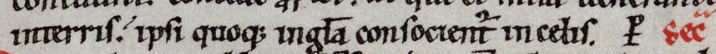

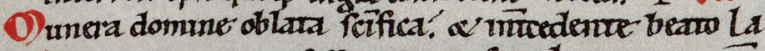

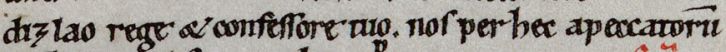
nioz macultr emunda. I

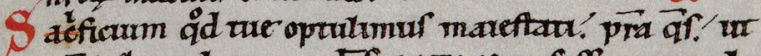

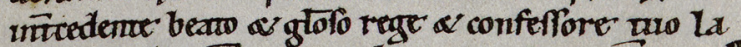
dizlao. ad wrarum remedurm tranfear alarum. If

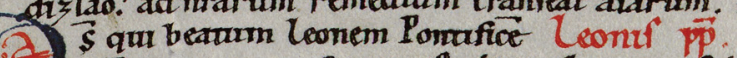

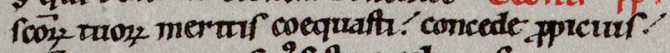

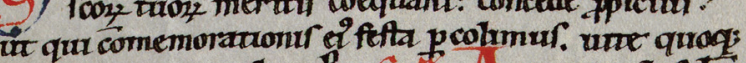

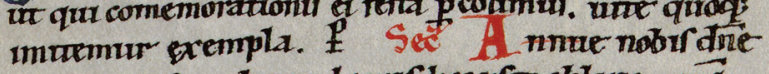
ux anzme famult arx leonur bexpfit oblacto. quad

imolando roce mundi tomith relayarz defica.

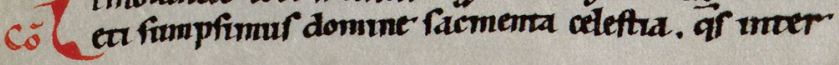

I2. kép: Könyörgések Szent László ünnepére a Pray-kódexből (Országos Széchényi Könyvtár, MNy I.; hu_bi_mnyi_02I7.jpg) 
További liturgikus alkotások is születtek Váradon. Így a misén énekelt szekvencia ${ }^{139}$ és a szent ünnepének fényét emelő verses zsolozsma (Historia ritmica), melyet részben a Legenda szövege inspirált. ${ }^{\mathrm{I}+0} \mathrm{Az}$ őslegendához is hozzányúltak, két változatban is kibővítették az újabb csodákkal. ${ }^{141}$

\footnotetext{
${ }^{339}$ Mezey: Athleta Patriae. A korai László-irodalom... (i. m.) 44. Szövegét lásd Török: Szent László a középkori magyarországi liturgiában (i. m.) 155-158.

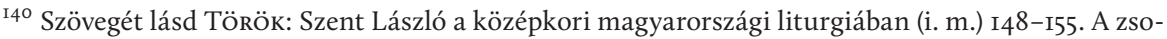
lozsmát részletesen tárgyalja Mezey: Athleta Patriae. A korai László-irodalom... (i. m.) 35-46. Vö. DoBszAy László: Az ország patrónusainak liturgikus tisztelete a középkori zsolozsmában. In: $M a-$ gyar szentek tisztelete és ereklyéi. Szerk. Cséfalvay Pál - Kontsek Ildikó. Esztergom, 2000, 99-Ioo. Korábbi megfogalmazása: Magyarország zenetörténete. I. Szerk. RAJEczKy Benjamin. Budapest, I988, 339-34I (Dobszay László írása). Mezey: Athleta Patriae. A korai László-irodalom... (i. m. 45-46) és Dobszay László feltételezi, hogy a francia hatást mutató zsolozsma a Párizsban tanult Elvinus váradi püspök munkája. Itt jelezzük, hogy Elvin váradi püspök párizsi tanulmányútja kétséges. A váradi statútumok püspöklistája szerint Elvin II89 és I20o között váradi püspök volt. BUNYıTAY: $A$ váradi káptalan... (i. m.) I5; Documenta Trans. (i. m.) 688. Vö. Zsoldos: Magyarország világi archontológiája (i. m.) 98. Bizonyos Elvinről viszont azt tudjuk, hogy III. Béla Iıg2-ben Párizsba küldte melódiát tanulni. Nehezen képzelhető el, hogy a püspököt küldték volna külföldre tanulni, ráadásul éppen II92-ben. Inkább fordítva szokott lenni: a Párizsban tanuló klerikusok hazatérésük után lettek föpapok, miként arra több példa is van ebből az időből. Ezt megfontolva arra lehet gondolni, hogy az évszám téves. Erre van is némi alapunk, mert az II92. évi adat Pray György I779. január 4-én írt levelében emlékezetből felidézett oklevélből való: sub Bela initium esse datum, in cuius diplomate anni II92 memini me legisse, Elvinum Parisios esse missum ad docendum melodiam. OSZK I834 Quart Lat. I. $78^{\text {r }}$ Ezt az adatot hasznosította Jean-Benjamin DE LA BORDE (1734-I794) francia zeneszerző és zenetörténész: Essai sur la musique ancienne et moderne. I. Paris, I780, I60. Vö. Isoz Kálmán: Pray György értekezése a magyarok zenéjéről. Zenei Szemle ıo (1926), 2II; Uő: Laborde forrása a magyar zenéről. Zenei Szemle I2 (1928), 73-74. Erről az oklevélről azonban Pray György és általa a francia zenetörténész említésén kívül nem tudunk semmit. Reg. Arp. 153. szám.

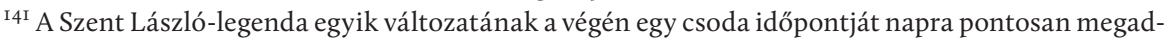
ták. A napot a római és a liturgikus naptár szerint is megjelölték. Mivel a két meghatározás nincs szinkronban egymással, Bartoniek Emma javította az I204-es évszámot I200-ra. SRH Il. 5II, 526 (I. jegyzet). Ugyanezt a korrekciót már régen megtették. Acta Sanctorum Junii. V. Antwerpiae I709, 3I9 („d” jegyzet). Ennek ellenére ezt a módosítást meglepő módon nem szokták figyelembe venni. A Legenda korai változatainak időrendjéről lásd SRH II. 509-5I3; SzovÁk Kornél: Szent László alakja a korai elbeszélő forrásokban. Századok I34 (2000), I32-I38, I4I-I42.
} 
Az exhumálást követően a földi maradványok egy részét nem temették el újra díszesebb helyen, hanem ereklyeként megtartották. Szent László nevezetes fejereklyéjének fordulatos története is ekkor vette kezdetét (I3. kép). ${ }^{142}$ A váradi püspök több egyházi intézménynek ajándékozott a csontmaradványokból. Az elsők között vagy éppen legelsőként ekkor kapott a szebeni prépostság Szent László-ereklyét, és lett ezzel a szentté avatott uralkodó a társaskáptalan égi patrónusa. ${ }^{143}$ A szent tiszteletére a váradi székesegyházban a sírnál oltárt emeltek. ${ }^{144}$

${ }^{142}$ IPOLYı Arnold: Magyar ereklyék. Archaeologiai Közlemények 3 (I863), 73-86. A fejereklyére tett esküről két biztos adatunk van. Lodomér váradi püspök oklevele örökítette meg I273-ban (és nem I275-ben), hogy a váradelőhegyi premontrei prépost és szerzetestársai előtt Egyed őrkanonok jelenlétében a váradi egyház népei tettek esküt a fejereklyére (super sanctissimum caput beatissimi regis Ladislai domini nostri in terris et patroni in celis), és ezzel döntötték el a váradi püspök és a káptalan közös birtokairól keletkezett vitát (uo. 74). DF 245023. (Arhivele Statului Sibiu, Szász Nemzeti Levéltár: Urkunden.) Kiadása: Franz Zimmermann - Carl Werner: Urkundenbuch zur Geschichte der Deutschen in Siebenbürgen. I. Hermannstadt, I892, I22-I23. A másik sajátos esküről Zsigmond király I406-ban kiadott adománylevelének elbeszélő része tájékoztat. Eszerint I403 elején a fôpapok és a világi előkelők nagyobb csoportja tett esküt a fejereklyére azzal a szándékkal, hogy Zsigmondot megfosztják trónjától, és László nápolyi királyt választják meg helyette. Hazai Okmánytár. Codex diplomaticus patrius. VII. Kiadják IPOLYı Arnold, NAGY Imre és VÉGHely Dezső. Budapest, I88o, 439-440. Vö. Középkori históriák oklevelekben (IOO2-I4IO). Szerk. KRisTó Gyula. (Szegedi Középkortörténeti Könyvtár, I.). Szeged, I992, 26I-262 (KAPITÁNFFy István fordítása); Fedeles Tamás: „Ad visitandumque sepulchrum sanctissimi regis Ladislai”. Várad kegyhelye a késő középkorban. In: „Köztes-Európa” vonzásában. Ünnepi tanulmányok Font Márta tiszteletére. Szerk. BAGı Dániel - FEDELES Tamás - Kiss Gergely. Pécs, 20I2, I75-I76. A herma első leírását a székesegyház I557. évi leltárából ismerjük. Ugyanebből a forrásból tudjuk, hogy helye a Szent László-kápolnában volt. MıKó-MolnÁR: A váradi középkori székesegyház... (i. m.) 304, 305, 307, 316 (287. tétel). Ez a kápolna minden bizonnyal a szentélyt ölelő I4. századi kápolnakoszorú egyik alkotóeleme lehetett.

${ }^{143}$ A szebeni egyház eredeti védőszentjének nevét nem ismerjük. Szent László iıg2-ben valószínűleg társpatrónus lett, majd idővel háttérbe szorult, és végül feledésbe merült az eredeti, számunkra ismeretlen patrocínium. Vö. THOROczKaY: A szebeni prépostság... (i. m.) 4I.

${ }^{144}$ Post canonisationem autem sancti regis Ladislai institutum fuit ad eius sepulchrum sub eius titulo altare. Bunyitay: A váradi káptalan... (i. m.) 71; Documenta Trans. (i. m.) 713. A váradi székesegyház Szent László-oltárának első említését annak köszönhetjük, hogy I229-ben kivételesen nem a sírnál, az ereklyéknél, hanem ennél az oltárnál tettek esküt. Reg. Varad. 362. szám. 


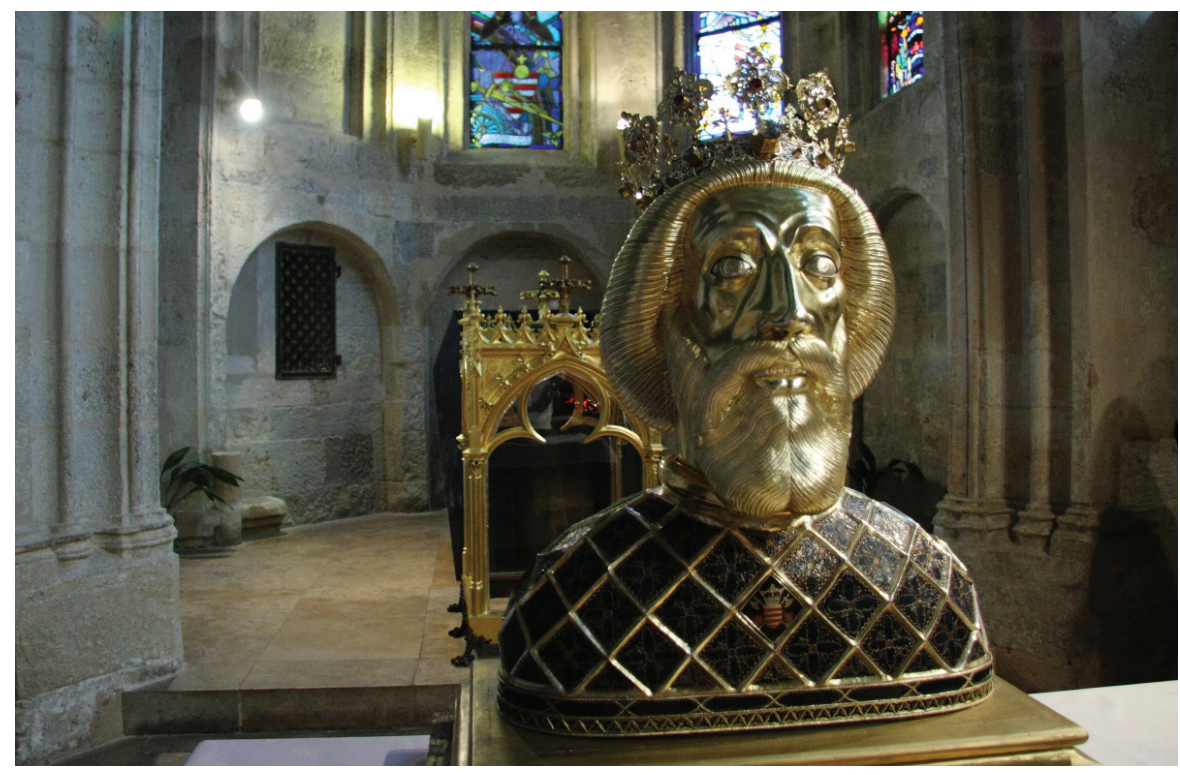

I3. kép: Szent László hermája a győri székesegyházban (Nagy Károly Zsolt felvétele)

Sok helyen templomokat építettek, és a névadási gyakorlatnak megfelelően a templom Szent László titulusa gyakran a település nevében is kifejeződött. ${ }^{145}$ A kultusz átlépte a váradi egyházmegye határait, és hamarosan országossá vált. ${ }^{{ }^{4}{ }^{6}}$ Ebben a folyamatban nyilvánvalóan jelentős részük volt azoknak az egyházi intézményeknek, amelyeket Szent László alapított vagy legalább adománynyal gazdagított. ${ }^{147}$ A szentté avatott uralkodó ismertsége, a királyi udvar és a fópapok szerepe is gyorsította az országos elterjedést. Ebben sokat segített, hogy már régóta olvasható volt az ismeretlen krónikás összefoglalója az uralkodó eseményekben gazdag életéről. ${ }^{148}$

\footnotetext{
${ }^{145}$ Mező: Patrocíniumok... (i. m.) 2II-22I.

${ }^{146}$ MADAS: Sermones... (i. m.) I2-20; BÁLINT: Ünnepi Kalendárium (i. m.) 1. 480-504.

${ }^{147}$ Vö. Veszprémy: Az invesztitúra harcok királyképe... (i. m.) 44.

${ }^{148}$ SRH I. 366-420; GERICs: Krónikáink... (i. m.) II3-I36; újabb kiadásban: Uő: Egyház, állam és gondolkodás... (i. m.) I85-208; GeRıcs-LadánYı: Szent László „csodás” tettei... (i. m.) 20-32; Klaniczay: Szent László „csodás” tettei... (i. m.) 393-4I0; Uő: A Szent László-kultusz kialakulása (i. m.) 2I-3I. Vö. Bollók János: Szent László korának magyar értelmisége. Vigilia 65 (2000), 843; újabb kiadásban: Philologia nostra. Bollók János összegyüjtött tanulmányai. Szerk. MÉszÁros Tamás. (Antiquitas, Byzantium, Renascentia, 4.) Budapest, 2013, 427.
} 
Így nem meglepő, hogy a Szent László-zsolozsmában (meg a szekvenciában) a helyi kultusz mellett már az országos is helyet kapott. A szent király nem csupán Várad, hanem az egész magyar nép (Hungarorum gens) és Pannonia, azaz a Magyar Királyság büszkesége lett, sőt a himnusz műfajához illően, óhaj formájában „a haza fáradhatatlan védelmezője és bajnoka” (sis defensor indefessus et atletha patriae). ${ }^{149}$

Nem sokkal később kiegészítették az I092. évi Szabolcsi Zsinat ünneplistáját. ${ }^{150} \mathrm{Az}$ egész ország számára mintául szolgáló esztergomi ünneplajstromba pedig az I083-ban szentté avatott és a Szent László-legendában szereplő öt magyar szent ${ }^{151}$ mellé felvették Szent László ünnepét. Eszerint megkülönböztetett tisztelet illette meg a szent királyokat: Istvánt és Lászlót, Imre herceget, valamint Gellért püspököt, András és Benedek zoborhegyi remetéket. A bibliai ihletésű megfogalmazás szerint azért lettek méltóak az ünnepélyes tiszteletre, ünnepnapjuk megülésére, mert „az igen szerencsés Magyarország földjét az Úr szőlejében munkálkodva a keresztény tanítással teljesen átitatták" ${ }^{152}$ Illett ez az értékelés Szent László királyra is, hiszen a pogánylázadások és a trónharcok után sikerült megszilárdítania a keresztény életformát és továbbfejlesztenie az egyházszervezetet.

A változás további ékes bizonysága Imre király iıg8-ban kiadott oklevele. Ebben Szent István és Szent László neve (sanctissimus rex Stephanus et beatus Ladislaus rex) nemcsak egymás mellé került, mint az ünneplistában, hanem a két szent követendő minta lett Imre király számára. Miként az uralkodói jövedelmek tizedét a szent királyok az esztergomi érseknek adományozták (sicut per sanctos reges erant donate), úgy járt el ő is, sőt a szent királyok példájára (exemplo sancto-

\footnotetext{
${ }^{149}$ TöRÖK: Szent László a középkori magyarországi liturgiában (i. m.) I48-I49, I53, I56; MezeY: Athleta Patriae. A korai László-irodalom... (i. m.) 42, 44-45; Marosı Ernő: Szent László mint nemzeti szent. In: Uő: Kép és hasonmás. Művészet és valóság a I4-I5. századi Magyarországon. (Művészettörténeti Füzetek, 23.) Budapest, I995, 76-77, I99 (348. jegyzet). Vö. KurCZ Ágnes: Lovagi kultúra Magyarországon a I3-I4. században. Budapest, I988, 2 II.

${ }^{150}$ Závodszky: A Szent István, Szent László és Kálmán korabeli törvények... (i. m.) I64 (38. cikkely).

${ }^{151}$ SRH Il. 520-52I.

${ }^{152}$ Solymosı László: Az esztergomi egyházmegye legrégebbi ünneplajstroma (Szent Adalbert, Szórád-András és Benedek tisztelete az erdélyi szászoknál). In: $R$. Várkonyi Ágnes Emlékkönyv. Szerk. Tusor Péter. Szerkesztőtársak: Rihmer Zoltán és THOROczKaY Gábor. Budapest, I998, 93-94.
} 
rum regum) az esztergomi várban épülő királyi lakóházat is az esztergomi érseknek adományozta (I4. kép). ${ }^{153}$

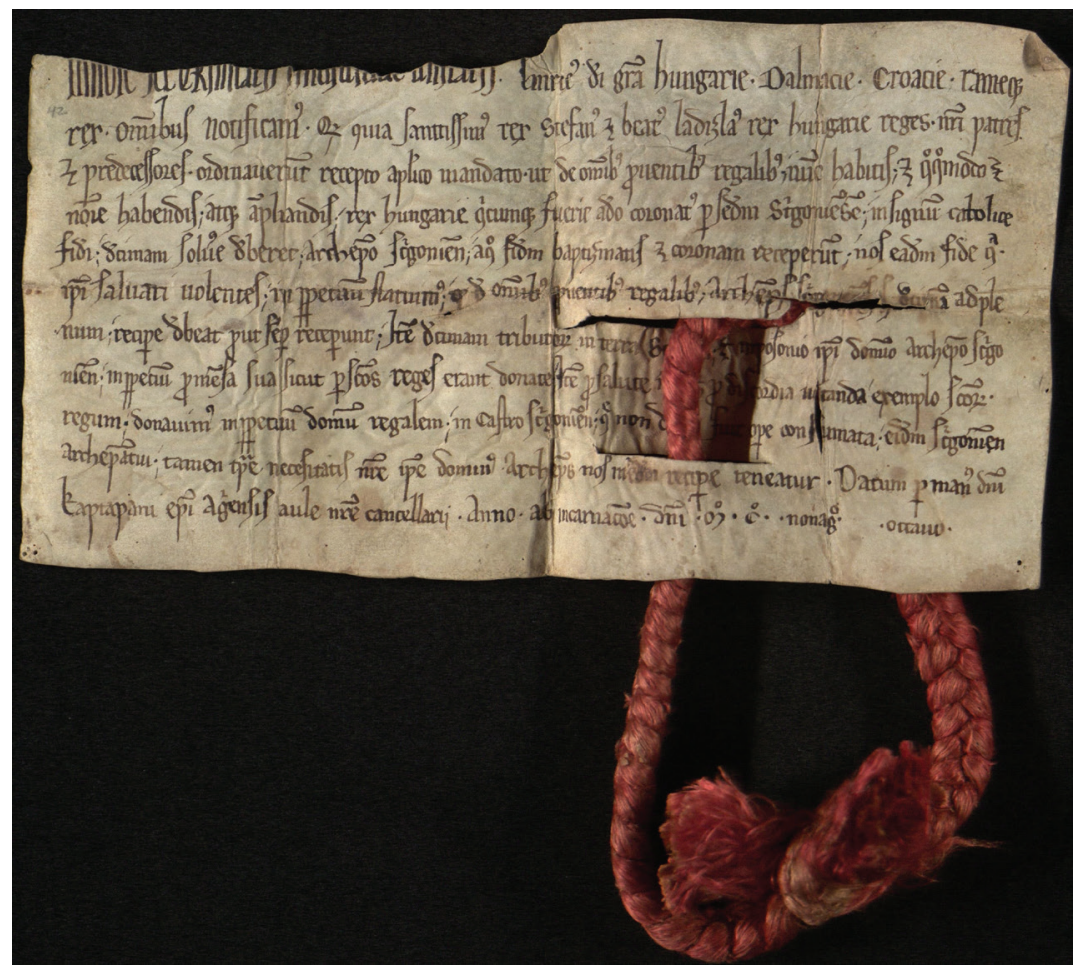

I4. kép: Szent István és Szent László mint példamutató szent királyok Imre király II98. évi oklevelében (Prímási Levéltár Archivum Saeculare, Acta radicalia, I-I.)

Összességében i2oo táján minden adott volt ahhoz, hogy a szentté avatott magyar király tisztelete az egész országban elterjedjen, müvészi ábrázolások sokasága örökítse meg a lovagszent uralkodót (I5. kép), és Szent László a középkori Magyar Királyság legnépszerűbb szentjévé, népmondai hősévé váljon.

${ }^{153}$ DF 248310. (Prímási Levéltár, Archivum Saeculare, Acta radicalia I-I.) Kiadása: Mon. Strig. I. 156. Idézi: FehÉrtóı Katalin: Árpád-kori személynévtár (IOOO-I3OI). Budapest, 2004, 478. Vö. Reg. Arp. I77. szám. A Váradhoz szorosan kötődő Szent László-kutatás figyelmét minden bizonnyal azért kerülte el ez az oklevél, mert az esztergomi vonatkozású forrásnak nincs semmi köze Váradhoz. 


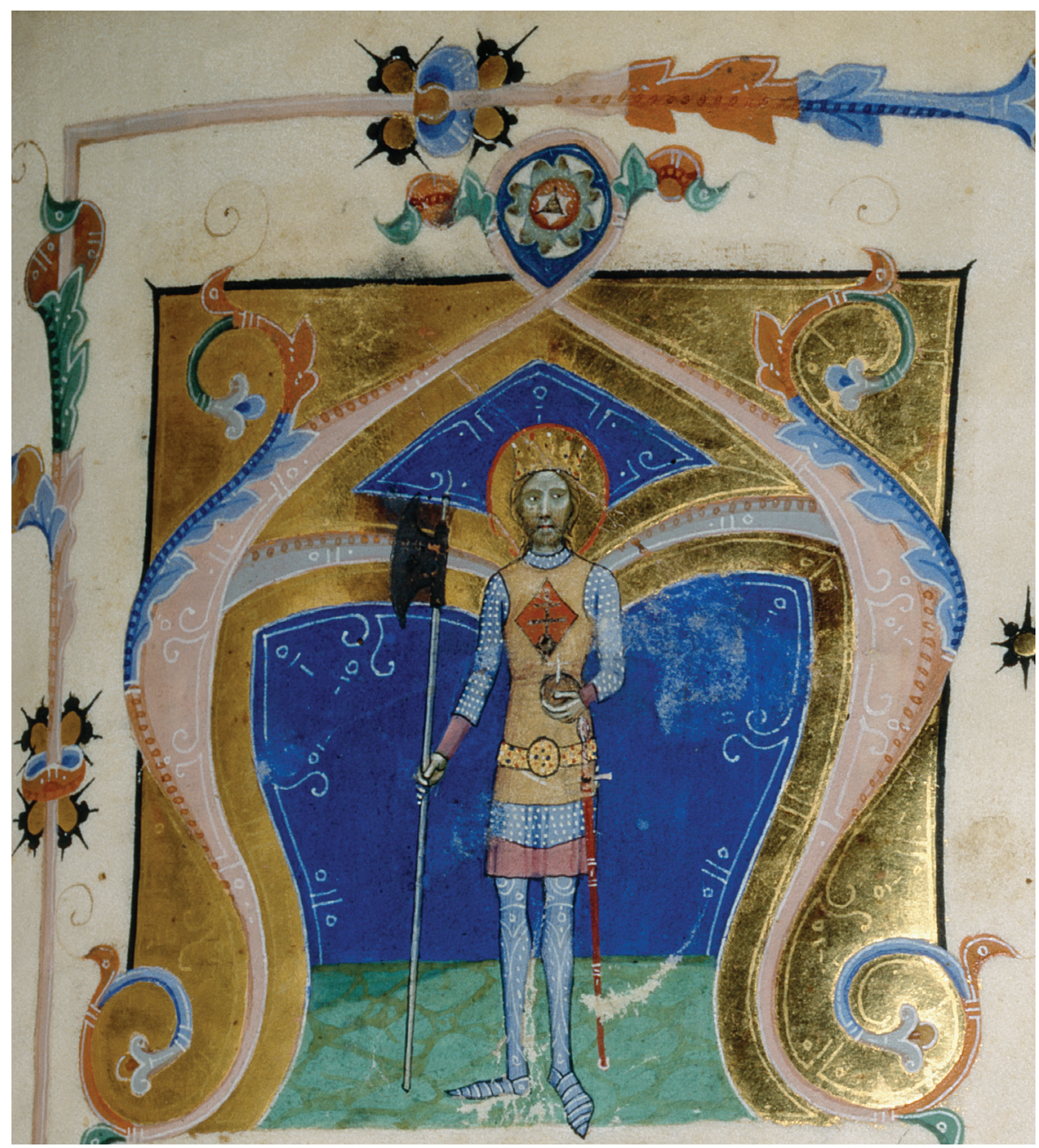

I5. kép: Szent László király a Képes krónikában (Országos Széchényi Könyvtár, Képes krónika 47²) 
- 
- 
